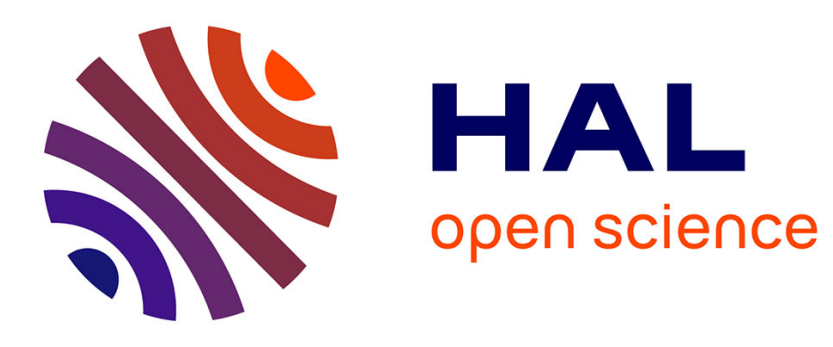

\title{
Doping effect on the structure and properties of eight-electron silver nanoclusters
}

Yu-Jie Zhong, Jian-Hong Liao, Tzu-Hao Chiu, Franck Gam, Samia Kahlal, Jean-Yves Saillard, C W Liu

\section{- To cite this version:}

Yu-Jie Zhong, Jian-Hong Liao, Tzu-Hao Chiu, Franck Gam, Samia Kahlal, et al.. Doping effect on the structure and properties of eight-electron silver nanoclusters. Journal of Chemical Physics, 2021, 155 (3), pp.034304. 10.1063/5.0059305 . hal-03333744

\section{HAL Id: hal-03333744 \\ https://hal.science/hal-03333744}

Submitted on 16 Sep 2021

HAL is a multi-disciplinary open access archive for the deposit and dissemination of scientific research documents, whether they are published or not. The documents may come from teaching and research institutions in France or abroad, or from public or private research centers.
L'archive ouverte pluridisciplinaire HAL, est destinée au dépôt et à la diffusion de documents scientifiques de niveau recherche, publiés ou non, émanant des établissements d'enseignement et de recherche français ou étrangers, des laboratoires publics ou privés. 


\title{
Doping Effect on the Structure and Properties of Eight-
}

\section{Electron Silver Nanoclusters}

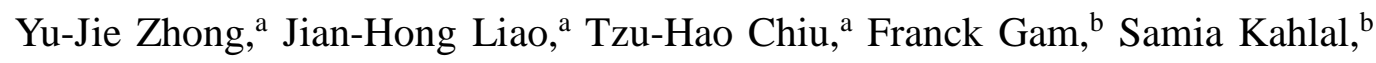
Jean-Yves Saillard, ${ }^{* b}$ C. W. Liu*a

${ }^{a}$ Department of Chemistry, National Dong Hwa University, Hualien 974301, Taiwan (Republic of China). E-mail: chenwei@gms.ndhu.edu.tw; http://faculty.ndhu.edu.tw/ cwl/index.htm

b Univ Rennes, CNRS, ISCR-UMR 6226, F-35000 Rennes, France.

\begin{abstract}
The bimetallic $\mathrm{M}_{20}$ and $\mathrm{M}_{21}$ compounds, $\left\{\left[\mathrm{Cu}_{3} \mathrm{Ag}_{17}\left\{\mathrm{~S}_{2} \mathrm{P}\left(\mathrm{O}^{i} \mathrm{Pr}\right)_{2}\right\}_{12}\right]_{0.5}\right.$ $\left.\left[\mathrm{Cu}_{4} \mathrm{Ag}_{16}\left\{\mathrm{~S}_{2} \mathrm{P}\left(\mathrm{O}^{i} \mathrm{Pr}\right)_{2}\right\}_{12}\right]_{0.5}\right\}\left(\left\{[\mathbf{1 a}]_{0.5}[\mathbf{1 b}]_{0.5}\right\}\right)$ and $\left[\mathrm{Cu}_{4} \mathrm{Ag}_{17}\left\{\mathrm{~S}_{2} \mathrm{P}\left(\mathrm{O}^{i} \mathrm{Pr}\right)_{2}\right\}_{12}\right]\left(\mathrm{PF}_{6}\right)$ (2) have been structurally characterized, in which the $\mathrm{Cu}(\mathrm{I})$ ions are randomly distributed on the eight outer positions capping the 8-electron $\left[\mathrm{Ag}_{13}\right]^{5+}$ core. DFT calculations show that his statistical disorder results from the nearly neutral preference of copper to occupy any of the eight outer positions. Surprisingly, the UV-Vis absorption spectra of the $\mathrm{M}_{20}$ and $\mathrm{M}_{21}$ bimetallic nanoclusters display an almost identical absorption profile as that of their homometallic $\left[\mathrm{Ag}_{20}\left\{\mathrm{~S}_{2} \mathrm{P}\left(\mathrm{O}^{i} \mathrm{Pr}\right)_{2}\right\}_{12}\right]$ and $\left[\mathrm{Ag}_{21}\left\{\mathrm{~S}_{2} \mathrm{P}\left(\mathrm{O}{ }^{i} \mathrm{Pr}\right)_{2}\right\}_{12}\right]^{+}$ relatives. This is rationalized by TD-DFT calculations which show that the frontier orbitals of such 8-electron alloys are largely independent from the nature of the capping metal ions. A blue-shifted absorption is observed upon replacing by Au the central Ag atom in 2, forming the trimetallic compound $\left[\mathrm{Cu}_{4} \mathrm{AuAg}_{16}\left\{\mathrm{~S}_{2} \mathrm{P}\left(\mathrm{O}^{i} \mathrm{Pr}\right)_{2}\right\}_{12}\right]\left(\mathrm{PF}_{6}\right)(3)$.
\end{abstract}

\section{INTRODUCTION}

Ligand-protected noble metal nanoclusters (NCs) are hot targets to seek, due to their captivating structural characteristics and broad applications in a wide spectrum of fields. These include biological labelling, optoelectronics, sensing, and catalysis. ${ }^{1-5}$ One of the most topical branches deals with atomically precise superatomic NCs, for which it is possible to investigate accurately the structure-property relationships. ${ }^{6-7}$ For example, the photoluminescence property of NCs can be tuned by doping the parent homometallic NCs to trigger enhancements of emission intensity. ${ }^{8-10}$ From this viewpoint, structural analysis is indispensable and only through X-ray diffraction can we understand the detailed atomic arrangements in the NCs.

Alloying NCs under precise control at atomic level has long been a challenge. Recent studies on atomically precise, superatomic clusters of the type $M @ \operatorname{Ag}_{19+n}(M=A u$, 
Pd, Pt; $\mathrm{n}=0,{ }^{11} 1,{ }^{12-14} 5,{ }^{15-17} 9,{ }^{8} 14,{ }^{18} 20^{19}$ ), where the heteroatom $\mathrm{M}$ is lying at the center of an $\mathrm{Ag}_{12}$ icosahedron, to generate a kernel typically surrounded by $7+\mathrm{n}$ silver atoms, have explicitly demonstrated that electronic properties of 8-electron alloys can be tuned by the heterometal nature. Zhu and co-workers successfully pushed the boundary from mono-metallic to tetra-metallic in the case of $\mathrm{M}_{29} \mathrm{NCs} .{ }^{20}$ However, only one $\mathrm{Pt} / \mathrm{Ag} / \mathrm{Cu}$ trimetallic $\mathrm{NC}, \mathrm{PtAg}_{12} \mathrm{Cu}_{16}$, has been so far structurally characterized and displays a Pt-centered $\mathrm{Ag}_{12}$ cuboctahedron surrounded by $16 \mathrm{Cu}$ atoms. On the other hand, reports of Cu-doped Ag NCs are relatively few, ${ }^{20-22}$ especially for species in which $\mathrm{Cu}$ ions surround a centered icosahedral $\mathrm{M} @ \mathrm{Ag}_{12}$ core. Only two examples, $\mathrm{Ag}_{17} \mathrm{Cu}_{12}$ and $\mathrm{AuAg}_{16} \mathrm{Cu}_{12}$, can be found in the literature. ${ }^{22}$ Herein we present the effect of the formal doping with $\mathrm{Cu}$ of the related 8-electron homometallic $\left[\mathrm{Ag}_{20}\left\{\mathrm{~S}_{2} \mathrm{P}\left(\mathrm{O}^{i} \mathrm{Pr}\right)_{2}\right\}_{12}\right]^{23}$ and $\left[\mathrm{Ag}_{21}\left\{\mathrm{~S} 2 \mathrm{P}\left(\mathrm{O}^{i} \mathrm{Pr}\right)_{2}\right\}_{12}\right]^{+24}$ NCs. The later species, both of $C_{3}$ ideal symmetry, are made of an $\left[\mathrm{Ag} @ \mathrm{Ag}_{12}\right]^{5+}$ centered icosahedron capped by seven and eight $\mathrm{Ag}^{+}$outer atoms, respectively, and further wrapped up in a passivating shell made of twelve dithiophosphate $\left(\left[\mathrm{S}_{2} \mathrm{P}\left(\mathrm{O}^{i} \mathrm{Pr}\right)_{2}\right]^{-}\right)$ligands (abbreviated as dtp in the followings). In the doped species, the $\mathrm{Cu}$ heterometals only replace some of the capping Ag atoms at the surface of the 8-electron superatomic core.

\section{EXPERIMENTAL DETAILS}

\section{A. MATERIALS}

All chemicals used as received were purchased from commercial sources. Solvents were purified following standard protocols. ${ }^{25}$ All reactions were performed in ovendried Schlenk glassware using standard inert atmosphere techniques. All reactions were carried out under $\mathrm{N}_{2}$ atmosphere by using standard Schlenk techniques. $\left[\mathrm{M}\left(\mathrm{CH}_{3} \mathrm{CN}\right)_{4}\right] \mathrm{PF}_{6}(\mathrm{M}=\mathrm{Cu}, \mathrm{Ag}),{ }^{26}\left[\mathrm{Ag}_{20}\left\{\mathrm{~S}_{2} \mathrm{P}\left(\mathrm{O}^{i} \mathrm{Pr}\right)_{2}\right\}_{12}\right],{ }^{23}$ and $\mathrm{NH}_{4}\left[\mathrm{~S}_{2} \mathrm{P}\left(\mathrm{O}^{i} \mathrm{Pr}\right)_{2}\right]^{27}$ were prepared by procedures reported earlier in literature.

\section{B. INSTRUMENTATION}

${ }^{1} \mathrm{H}$ and ${ }^{31} \mathrm{P}\left\{{ }^{1} \mathrm{H}\right\}$ NMR spectra were recorded on a Bruker Avance DPX $300 \mathrm{MHz}$ NMR spectrometer, operating at $300.13 \mathrm{MHz}$ for ${ }^{1} \mathrm{H}$ and $121.49 \mathrm{MHz}$ for ${ }^{31} \mathrm{P}$. The chemical shifts ( $\delta$ ) and coupling constants (J) are reported in ppm and $\mathrm{Hz}$, respectively. X-ray diffraction data were collected on a Bruker APEX II CCD diffractometer. ESI mass spectra were recorded on a Fison Quattro Bio-Q (Fisons Instruments, VG Biotech, U. K.). UV-visible absorption spectra were measured on a Perkin Elmer Lambda 750 spectrophotometer using quartz cells with path length of $1 \mathrm{~cm}$. The elemental analyses (C, $\mathrm{H}$, and $\mathrm{S}$ content) of the sample were determined by an Elementar UNICUBE elemental analyzer. 


\section{COMPUTATIONAL DETAILS}

Geometry optimizations were carried out within the formalism of the density functional theory (DFT) with the Gaussian 16 package, ${ }^{28}$ using the BP86 functional ${ }^{29,30}$ and the Def2-TZVP basis set from EMSL Basis Set Exchange Library. ${ }^{31,32}$ All the optimized geometries were characterized as true minima by vibrational analysis. The compositions of the molecular orbitals were calculated using the AOMix program. ${ }^{33}$ The UV-visible transitions were calculated on the above-mentioned optimized geometries by means of time-dependent DFT (TD-DFT) calculations, with the CAMB3LYP functional ${ }^{34}$ and the Def2-TZVP basis set. The UV-visible spectra were simulated from the computed TD-DFT transitions and their oscillator strengths by using GaussView, ${ }^{35}$ each transition being associated with a Gaussian function of halfheight width equal to $1000 \mathrm{~cm}^{-1}$.

\section{SYNTHETIC PROCEDURE}

\section{1. $\left[\mathrm{Cu}_{x} \mathrm{Ag}_{20-\mathrm{x}}\left\{\mathrm{S}_{2} \mathrm{P}\left(\mathrm{O}^{i} \mathrm{Pr}\right)_{2}\right\}_{12}\right]$ (1), $\mathrm{x}=3$ (1a), 4 (1b).}

$\left[\mathrm{Ag}\left(\mathrm{CH}_{3} \mathrm{CN}\right)_{4}\right] \mathrm{PF}_{6}(0.256 \mathrm{~g}, 0.614 \mathrm{mmol}),\left[\mathrm{Cu}\left(\mathrm{CH}_{3} \mathrm{CN}\right)_{4}\right] \mathrm{PF}_{6}(0.141 \mathrm{~g}, 0.38$ mmol), and $\mathrm{NH}_{4}\left[\mathrm{~S}_{2} \mathrm{P}\left(\mathrm{O}^{i} \mathrm{Pr}\right)_{2}\right](0.131 \mathrm{~g}, 0.566 \mathrm{mmol})$ were added in a $250 \mathrm{~mL}$ flask and then THF $(50 \mathrm{~mL})$ was added. The solution was cooled to $-20^{\circ} \mathrm{C}$ and then $\mathrm{NaBH}_{4}$ (0.054 g, $\left.1.415 \mathrm{mmol}\right)$ was added. It was kept stirring for $4 \mathrm{~h}$ and dried under vacuum. The residual was dissolved in dichloromethane and passed through alumina column by gravity. The eluent was collected as $\left[\mathrm{Cu}_{x} \mathrm{Ag}_{7}\right.$ $\left.{ }_{x}(\mathrm{H})\left\{\mathrm{S}_{2} \mathrm{P}\left(\mathrm{O}^{i} \mathrm{Pr}\right)_{2}\right\}_{6}\right]^{36}$ The residues retained on the column can be flushed out by using acetone as eluting solvent. The eluent was collected and dried, and then washed by $n$-hexane $(10 \mathrm{~mL})$ and filtered. The filtrate was dried under vacuum to yield [ $\left.\mathrm{Cu}_{\mathrm{x}} \mathrm{Ag}_{20-\mathrm{x}}\left\{\mathrm{S}_{2} \mathrm{P}\left(\mathrm{O}^{i} \mathrm{Pr}\right)_{2}\right\}_{12}\right]$ (1) as a dark orange-red powder (Yield: $0.105 \mathrm{~g}$, 61.8\%, based on Ag). ${ }^{31} \mathrm{P}\left\{{ }^{1} \mathrm{H}\right\}$ NMR (121.49 MHz, $\left.\mathrm{CDCl}_{3}, \delta, \mathrm{ppm}\right)$ : 98.3. ${ }^{1} \mathrm{H}$ NMR (300.13 MHz, $\left.\mathrm{CDCl}_{3}, \delta, \mathrm{ppm}\right): 1.35\left(\mathrm{~d},{ }^{3} J_{\mathrm{HH}}=6 \mathrm{~Hz}, 144 \mathrm{H}, \mathrm{CH}_{3}\right), 4.94(\mathrm{~m}, 24 \mathrm{H}$, $\mathrm{CH})$. Anal. calcd. for $\mathrm{C}_{84} \mathrm{H}_{196} \mathrm{Ag}_{16.5} \mathrm{Cu}_{3.5} \mathrm{O}_{24} \mathrm{P}_{12} \mathrm{~S}_{24}\left([\mathbf{1 a}]_{0.5}[\mathbf{1 b}]_{0.5} \cdot 2\left(\mathrm{C}_{6} \mathrm{H}_{14}\right)\right)$ : C, 21.31; H, 4.17; S, 16.25. Found: C, 21.90; H, 4.15; S, 16.62. UV-vis [ $\lambda$ in nm ( $\varepsilon$ in $\left.\mathrm{M}^{-1} \mathrm{Cm}^{-1}\right)$ ]: 355 (4000), 422 (6100), 473 (2600).

\section{2. $\left[\mathrm{Cu}_{4} \mathrm{Ag}_{17}\left\{\mathrm{~S}_{2} \mathrm{P}\left(\mathrm{O}^{i} \mathrm{Pr}\right)_{2}\right\}_{12}\right] \mathrm{PF}_{6}(2)$}

Method A - A One-Pot Reaction: Compound $\mathbf{2}$ can be isolated from the synthetic procedure of $\mathbf{1}$. The reaction product was dissolved in dichloromethane and passed through alumina column by gravity. The residues retained on the column can be flushed out by using acetone as eluting solvent. The eluent was collected and dried, then washed by $n$-hexane $(10 \mathrm{~mL})$. The precipitate was collected by filtration, and 
dried under vacuum to yield $\left[\mathrm{Cu}_{4} \mathrm{Ag}_{17}\left\{\mathrm{~S}_{2} \mathrm{P}\left(\mathrm{O}^{i} \mathrm{Pr}\right)_{2}\right\}_{12}\right] \mathrm{PF}_{6}$ (2) a dark orange-red powder (Yield: $0.054 \mathrm{~g}, 64.3 \%$, based on Ag).

Method B - Doping Reaction: [ $\left.\mathrm{Ag}_{20}\left\{\mathrm{~S}_{2} \mathrm{P}\left(\mathrm{O}^{i} \mathrm{Pr}\right)_{2}\right\}_{12}\right](0.071 \mathrm{~g}, 0.015 \mathrm{mmol})$ and $\left[\mathrm{Cu}\left(\mathrm{CH}_{3} \mathrm{CN}\right)_{4}\right] \mathrm{PF}_{6}(0.056 \mathrm{~g}, 0.150 \mathrm{mmol})$ were charged in a flask and then THF $\left(20 \mathrm{~mL}\right.$ ) was added. The solution was stirred at $-20^{\circ} \mathrm{C}$ for $1 \mathrm{~h}$ and dried under vacuum. The residual was dissolved in dichloromethane $(20 \mathrm{~mL})$ and washed with deionized water (10 $\mathrm{mL}$ x 3). The organic layer was collected and filtered. The filtrate was dried and washed by $n$-hexane, and then dried under vacuum to yield $\left[\mathrm{Cu}_{4} \mathrm{Ag}_{17}\left\{\mathrm{~S}_{2} \mathrm{P}\left(\mathrm{O}^{i} \mathrm{Pr}\right)_{2}\right\}_{12}\right] \mathrm{PF}_{6}$ (2) as a dark orange-red powder (Yield: $0.062 \mathrm{~g}$, 86.3\%, based on Ag). ${ }^{31} \mathrm{P}\left\{{ }^{1} \mathrm{H}\right\}$ NMR (121.49 MHz, $\mathrm{CDCl}_{3}, \delta$, ppm): 93.5 (s, $S_{2} P$ ), -143.0 (septet, $\left.{ }^{1} J_{\mathrm{PF}}=710 \mathrm{~Hz}, \mathrm{PF}_{6}\right) .{ }^{1} \mathrm{H}$ NMR (300.13 MHz, $\left.\mathrm{CDCl}_{3}, \delta, \mathrm{ppm}\right): 1.36$ $\left(\mathrm{d},{ }^{3} J_{\mathrm{HH}}=6 \mathrm{~Hz}, 144 \mathrm{H}, \mathrm{CH}_{3}\right), 4.87(\mathrm{~m}, 24 \mathrm{H}, \mathrm{CH})$. Anal. calcd. for $\mathrm{C}_{72} \mathrm{H}_{168} \mathrm{Ag}_{17} \mathrm{Cu}_{4} \mathrm{~F}_{6} \mathrm{O}_{24} \mathrm{P}_{13} \mathrm{~S}_{24} \cdot\left(\mathrm{CDCl}_{3}\right)$ : C, 17.85; H, 3.49; S, 15.66. Found: C, 17.53; $\mathrm{H}, 3.42$; S, 15.32. UV-vis [ $\lambda$ in $\mathrm{nm}\left(\varepsilon\right.$ in $\left.\left.\mathrm{M}^{-1} \mathrm{~cm}^{-1}\right)\right]$ : 382 (3900), 422 (5600), 480 (2400).

\section{3. $\left[\mathrm{Cu}_{4} \mathrm{AuAg}_{16}\left\{\mathrm{~S}_{2} \mathrm{P}\left(\mathrm{O}^{i} \mathrm{Pr}\right)_{2}\right\}_{12}\right] \mathrm{PF}_{6}$ (3)}

Compound 2 ( $0.114 \mathrm{~g}, 0.024 \mathrm{mmol}$, based on the molecular formula in crystal 2) was dissolved in THF $(20 \mathrm{~mL})$ and cooled to $-20^{\circ} \mathrm{C} . \mathrm{Au}\left(\mathrm{PPh}_{3}\right) \mathrm{Cl}(0.015 \mathrm{~g}, 0.030$ mmol) was added and kept stirring at same temperature for $1 \mathrm{~h}$. The solution was dried and the residue was washed by $n$-hexane to yield [Cu $\left.4 \mathrm{Cu}_{4} \mathrm{Ag}_{16}\left\{\mathrm{~S}_{2} \mathrm{P}\left(\mathrm{O}^{i} \mathrm{Pr}\right)_{2}\right\}_{12}\right] \mathrm{PF}_{6}$ as a dark orange-red powder (Yield: $0.103 \mathrm{~g}$, 88.8\%, based on Ag). ${ }^{31} \mathrm{P}\left\{{ }^{1} \mathrm{H}\right\}$ NMR (121.49 MHz, $\mathrm{CDCl}_{3}, \delta$, ppm): 93.6 (s, $S_{2} P$ ), -143.0 (septet, ${ }^{1} J_{\mathrm{PF}}=710 \mathrm{~Hz}, \mathrm{PF}_{6}$ ). ${ }^{1} \mathrm{H}$ NMR (300.13 MHz, $\left.\mathrm{CDCl}_{3}, \delta, \mathrm{ppm}\right): 1.36$ $\left(\mathrm{d},{ }^{3} \mathrm{~J}_{\mathrm{HH}}=6 \mathrm{~Hz}, 144 \mathrm{H}, \mathrm{CH}_{3}\right), 4.87(\mathrm{~m}, 24 \mathrm{H}, \mathrm{CH})$. Anal. calcd. for $\mathrm{C}_{72} \mathrm{H}_{168} \mathrm{Ag}_{16} \mathrm{AuCu}_{4} \mathrm{~F}_{6} \mathrm{O}_{24} \mathrm{P}_{13} \mathrm{~S}_{24} \cdot 2\left(\mathrm{C}_{6} \mathrm{H}_{14}\right): \mathrm{C}, 19.96 ; \mathrm{H}, 3.91 ; \mathrm{S}, 15.23$. Found: $\mathrm{C}$, 20.12; H, 3.67; S, 15.77. UV-vis [ $\lambda$ in $\mathrm{nm}\left(\varepsilon\right.$ in $\left.\left.\mathrm{M}^{-1} \mathrm{~cm}^{-1}\right)\right]$ : 373 (4100), 413 (4700), $464(2100)$.

\section{E. X-ray crystallography}

Single crystals suitable for X-ray diffraction analysis of $\mathbf{1}$ and $\mathbf{2}$ were obtained by slow evaporation of acetone solution at ambient temperature within a week. Single crystals were mounted on the tip of glass fiber coated in paratone oil and then transferred into the cold $\mathrm{N}_{2}$ gas stream. Data were collected on a Bruker APEX II CCD diffractometer using graphite monochromated Mo K $\alpha$ radiation $(\lambda=0.71073$ $\AA$ ) at $150 \mathrm{~K}$. Absorption corrections for area detector were performed with SADABS $^{37}$ and the integration of raw data frame was performed with SAINT. ${ }^{38}$ The structure was solved by direct methods and refined by least-squares against 
$F^{2}$ using the SHELXL-2018/3 package, ${ }^{39}$ incorporated in SHELXTL/PC V6.14. ${ }^{40}$ Both $\mathrm{Cu}$ and $\mathrm{Ag}$ atoms are randomly disordered on capping atom positions and detailed refinements of the occupancy ratios are depicted in FIG. 1-2.

In the preliminary refinement of $\mathbf{1}\left(\left\{[\mathbf{1} \mathbf{a}]_{0.5}[\mathbf{1 b}]_{0.5}\right\}\right)$, the 20 metal sites were anisotropically refined with 20 fully occupied Ag atoms as a starting model. As a result, electron holes only appeared around the seven $\mathrm{M}_{\text {cap }}$ positions. The largest electron hole $\left(\sim-4.0 \mathrm{e}^{-3}\right)$ was located around Ag17, which corresponds to the largest $\mathrm{Cu}$ :Ag occupancy ratio (0.75:0.25) in the final refinement (FIG. 1). The Cu: Ag occupancy ratio of each $M_{\text {cap }}$ positions was eventually determined as shown in FIG 1 by referring to the optimization result with free variables. The final refinement revealed that a total number of 3.5 $\mathrm{Cu}$ atoms were randomly distributed in the seven $\mathrm{M}_{\text {cap }}$ positions, which can be attributed to the co-crystallization of [Ag13@Cu $\left.\mathrm{Ag}_{4}\left\{\mathrm{~S}_{2} \mathrm{P}\left(\mathrm{O}^{i} \mathrm{Pr}\right)_{2}\right\}_{12}\right]$ (1a) and $\left[\mathrm{Ag}_{13} @ \mathrm{Cu}_{4} \mathrm{Ag}_{3}\left\{\mathrm{~S}_{2} \mathrm{P}\left(\mathrm{O}^{i} \mathrm{Pr}\right)_{2}\right\}_{12}\right]$ (1b) with equal ratio. The final $\mathrm{R} 1[\mathrm{I}>2 \sigma(\mathrm{I})]$ and $w \mathrm{R} 2$ (all data) value was reduced by $\sim 0.08$ and $\sim 0.04$, respectively, compared to the initial non-disordered model of $\left[\mathrm{Ag}_{20}\left\{\mathrm{~S}_{2} \mathrm{P}\left(\mathrm{O}^{i} \mathrm{Pr}\right)_{2}\right\}_{12}\right]$.

The same method was applied to the refinement of 2, with $\left[\mathrm{Ag}_{21}\left\{\mathrm{~S}_{2} \mathrm{P}\left(\mathrm{O}^{i} \mathrm{Pr}\right)_{2}\right\}_{12}\right] \mathrm{PF}_{6}$ as a starting model in the preliminary refinement. Again, the electron holes only appeared around the eight $\mathrm{M}_{\text {cap }}$ positions, and the $\mathrm{Cu}: \mathrm{Ag}$ occupancy ratio at each $\mathrm{M}_{\text {cap }}$ position was eventually determined as depicted in FIG 2. Besides, two additional $\mathrm{M}_{\text {cap }}$ (cyan color in FIG. 2) positions were identified as a minor contribution (10\%) to form pseudo-isomers of $\mathrm{M}_{21}$ skeleton, resulting from different arrangements of the $\mathrm{M}_{\text {cap }}$ atoms. It is noted that a similar situation was found in the previously published $\left[\mathrm{Ag}_{21}\left\{\mathrm{~S}_{2} \mathrm{P}\left(\mathrm{O}^{i} \mathrm{Pr}\right)_{2}\right\}_{12}\right] \mathrm{PF}_{6},{ }^{24}$ in which a minor contribution (15\%) was also uncovered. In the final refinement, a total of four $\mathrm{Cu}$ atoms were found to be randomly disordered at eight $\mathrm{M}_{\text {cap }}$ positions. Hence, the molecular formula in $\mathbf{2}$ is $\left[\mathrm{Ag}_{13} @ \mathrm{Cu}_{4} \mathrm{Ag}_{4}\left\{\mathrm{~S}_{2} \mathrm{P}\left(\mathrm{O}^{i} \mathrm{Pr}\right)_{2}\right\}_{12}\right] \mathrm{PF}_{6}$. Only the major contribution model (90\%) in structure 2 will be used for discussion in the following sections.

All non-hydrogen atoms were refined anisotropically. CCDC 2073787 (1) and 2057371 (2) contain the supplementary crystallographic data for compounds $\mathbf{1}$ and $\mathbf{2}$ in this article. These data can be obtained free of charge from The Cambridge Crystallographic Data Centre via www. ccdc.cam.ac.uk/data_request/cif. 


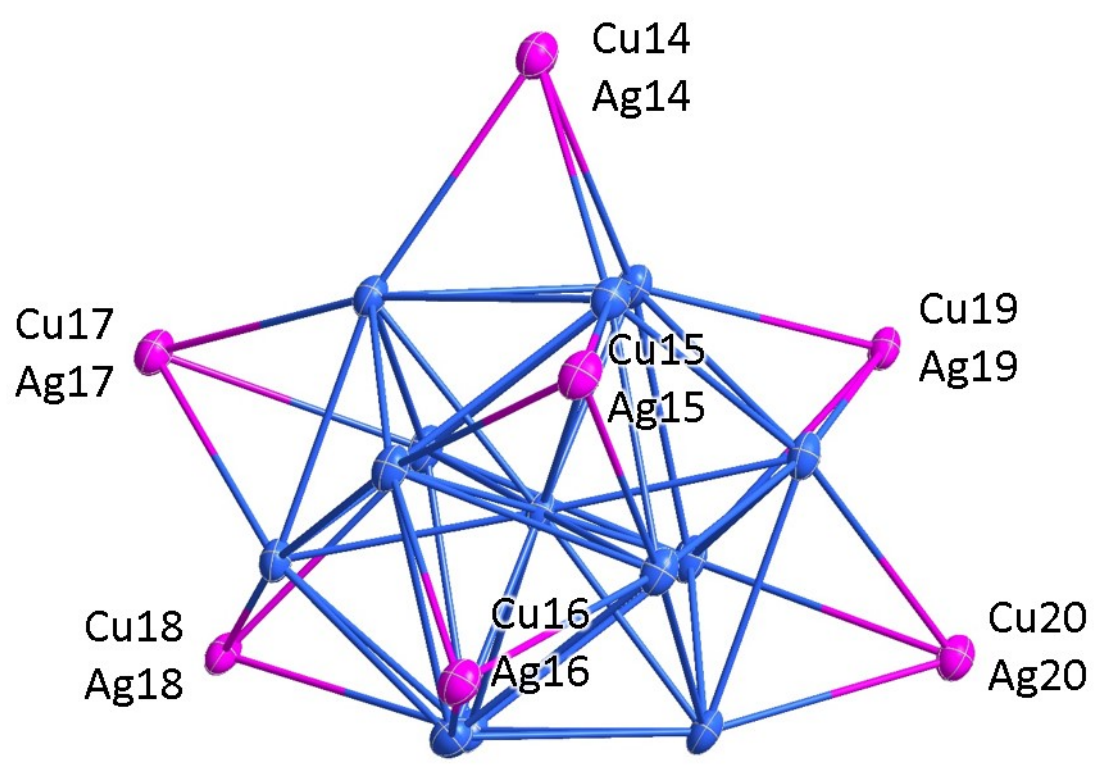

\begin{tabular}{|c|c|c|c|c|c|c|c|c|}
\hline $\begin{array}{c}\text { Atomic site } \\
\text { on } \mathrm{M}_{\text {cap }}\end{array}$ & $\begin{array}{c}\mathrm{Cu} 14 / \\
\mathrm{Ag} 14\end{array}$ & $\begin{array}{c}\mathrm{Cu} 15 / \\
\mathrm{Ag} 15\end{array}$ & $\begin{array}{c}\text { Cu16/ } \\
\mathrm{Ag} 16\end{array}$ & $\begin{array}{c}\text { Cu17/ } \\
\mathrm{Ag} 17\end{array}$ & $\begin{array}{c}\text { Cu18/ } \\
\mathrm{Ag} 18\end{array}$ & $\begin{array}{c}\text { Cu19/ } \\
\text { Ag19 }\end{array}$ & $\begin{array}{c}\text { Cu20/ } \\
\text { Ag20 }\end{array}$ & $\begin{array}{c}\text { Total } \\
\text { occupancy }\end{array}$ \\
\hline $\begin{array}{c}\mathrm{Cu} \\
\text { occupancy }\end{array}$ & 0.25 & 0.6 & 0.5 & 0.75 & 0.5 & 0.5 & 0.4 & 3.5 \\
\hline $\begin{array}{c}\mathrm{Ag} \\
\text { occupancy }\end{array}$ & 0.75 & 0.4 & 0.5 & 0.25 & 0.5 & 0.5 & 0.6 & 3.5 \\
\hline $\begin{array}{c}\text { Total } \\
\text { occupancy }\end{array}$ & 1 & 1 & 1 & 1 & 1 & 1 & 1 & 7 \\
\hline
\end{tabular}

FIG. 1. The $M_{20}$ metal framework of $\left\{[\mathbf{1} \mathbf{a}]_{0.5}[\mathbf{1 b}]_{0.5}\right\}$ (thermal ellipsoid plots were drawn at the $30 \%$ probability level), with the refined occupancy ratios of the seven $\mathrm{M}_{\text {cap }}$ positions (magenta color). 

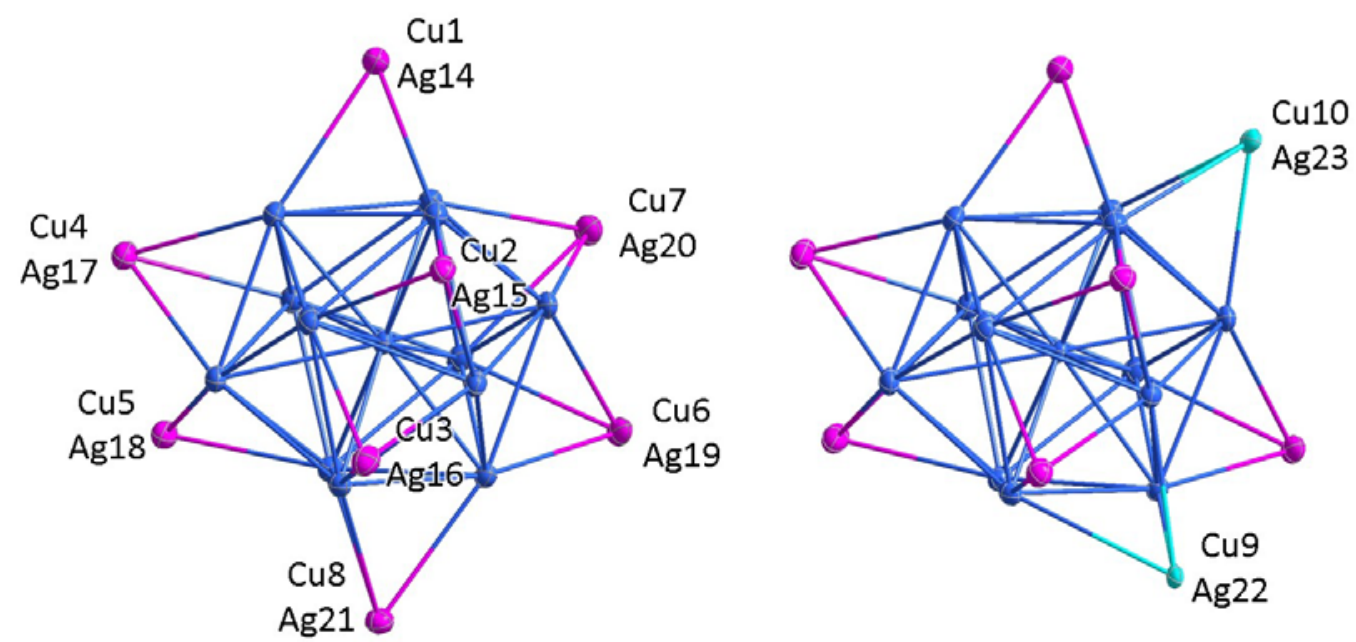

Major contribution (90\%)

Minor contribution (10\%)

\begin{tabular}{|c|c|c|c|c|c|c|c|c|c|c|c|}
\hline $\begin{array}{c}\text { Atomic } \\
\text { site on } \\
\mathrm{M}_{\text {cap }}\end{array}$ & $\begin{array}{c}\mathrm{Cu} 1 / \\
\mathrm{Ag} 14\end{array}$ & $\begin{array}{c}\mathrm{Cu} 2 / \\
\mathrm{Ag} 15\end{array}$ & $\begin{array}{c}\mathrm{Cu} / \\
\mathrm{Ag} 16\end{array}$ & $\begin{array}{c}\mathrm{Cu} 4 / \\
\mathrm{Ag} 17\end{array}$ & $\begin{array}{c}\mathrm{Cu} / \\
\mathrm{Ag} 18\end{array}$ & $\begin{array}{c}\mathrm{Cu} / \\
\mathrm{Ag} 19\end{array}$ & $\begin{array}{c}\mathrm{Cu} / / \\
\mathrm{Ag} 20\end{array}$ & $\begin{array}{c}\text { Cu8/ } \\
\mathrm{Ag} 21\end{array}$ & $\begin{array}{c}\text { Cu9/ } \\
\mathrm{Ag} 22\end{array}$ & $\begin{array}{c}\text { Cu10/ } \\
\mathrm{Ag} 23\end{array}$ & $\begin{array}{c}\text { Total } \\
\text { occupancy }\end{array}$ \\
\hline $\begin{array}{c}\mathrm{Cu} \\
\text { occupancy }\end{array}$ & 0.4 & 0.55 & 0.4 & 0.55 & 0.6 & 0.5 & 0.4 & 0.5 & 0.05 & 0.05 & 4 \\
\hline $\begin{array}{c}\mathrm{Ag} \\
\text { occupancy }\end{array}$ & 0.6 & 0.45 & 0.6 & 0.45 & 0.4 & 0.5 & 0.5 & 0.4 & 0.05 & 0.05 & 4 \\
\hline $\begin{array}{c}\text { Total } \\
\text { occupancy }\end{array}$ & 1 & 1 & 1 & 1 & 1 & 1 & 0.9 & 0.9 & 0.1 & 0.1 & 8 \\
\hline
\end{tabular}

FIG. 2. The $M_{21}$ metal framework of $2 \mathbf{a}$ (thermal ellipsoid plots were drawn at the $30 \%$ probability level), with the refined occupancy ratios of the eight $\mathbf{M}_{\text {cap }}$ positions.

\section{RESULTS AND DISCUSSIONS}

\section{A. Syntheses}

In this work, two bimetallic Cu-Ag NCs, $\left[\mathrm{Cu}_{\mathrm{x}} \mathrm{Ag}_{20-\mathrm{x}}\left\{\mathrm{S}_{2} \mathrm{P}\left(\mathrm{O}^{i} \mathrm{Pr}\right)_{2}\right\}_{12}\right]$ (1) $[\mathrm{x}=3$ (1a), 4 (1b)], and $\left[\mathrm{Cu}_{4} \mathrm{Ag}_{17}\left\{\mathrm{~S}_{2} \mathrm{P}\left(\mathrm{O}^{i} \mathrm{Pr}\right)_{2}\right\}_{12}\right]^{+}$(2), as well as a trimetallic NC, $\left[\mathrm{Cu}_{4} \mathrm{AuAg}{ }_{16}\left\{\mathrm{~S}_{2} \mathrm{P}\left(\mathrm{O}^{i} \mathrm{Pr}\right)_{2}\right\}_{12}\right]^{+}$(3) have been successfully prepared. 1 and 2 were generated from the one-pot reaction of $\mathrm{Cu}(\mathrm{I}), \mathrm{Ag}(\mathrm{I}),\left[\mathrm{S}_{2} \mathrm{P}\left(\mathrm{O}^{i} \mathrm{Pr}\right)_{2}\right]^{-}$, and $\mathrm{NaBH}_{4}$ with molar ratios of $\mathrm{Cu}^{+}: \mathrm{Ag}^{+}: \mathrm{L}^{-}: \mathrm{H}^{-}=$8:13:12:30 (SCHEME 1a; Method A, see experimental section). $\mathbf{1}$ and $\mathbf{2}$ can be easily separated by solvents in which the neutral species $\mathbf{1}$ is highly soluble in $n$-hexane but the cationic cluster $\mathbf{2}$ is not. An alternative way in the preparation of compound 2 is doping $\left[\mathrm{Ag}_{20}\left\{\mathrm{~S}_{2} \mathrm{P}\left(\mathrm{O}^{i} \mathrm{Pr}\right)_{2}\right\}_{12}\right]$ with $\mathrm{Cu}(\mathrm{I})$ (SCHEME 1b; Method B, see experimental section). Only $\mathrm{M}_{21}$ NCs can be isolated in this reaction, which indicates that both metal exchange and metal addition have occurred on the surface of the $\left[\mathrm{Ag}_{13}\right]^{5+}$ kernel. In the presence of an excess of metal ions, the metal tends to fill up the cavities on the surface. Therefore, the cluster nuclearity increases 
from 20 to 21. Such an addition reaction with cluster nuclearity increment has been previously described by us ${ }^{12}$ upon the addition of $\mathrm{Ag}^{+}$ions to $\left[\mathrm{Ag}_{20}\left\{\mathrm{~S}{ }_{2} \mathrm{P}\left(\mathrm{O}{ }^{i} \mathrm{Pr}\right)_{2}\right\}_{12}\right.$, which produces $\left[\mathrm{Ag}_{21}\left\{\mathrm{~S}_{2} \mathrm{P}\left(\mathrm{O}^{i} \mathrm{Pr}\right)_{2}\right\}_{12}\right]^{+}$in high yield. ${ }^{41} \mathrm{~A}$ further reaction by doping 2 with single $\mathrm{Au}^{+}$leads to the formation of the trimetallic NC 3 (SCHEME 1c). It is of note that increasing the amount of $\mathrm{Cu}(\mathrm{I})$ ions in the reactions leads to the decomposition of the NCs. Thus it seems to be difficult to replace all the capping silver atoms by $\mathrm{Cu}$ atoms in the 8-electron $\mathrm{Ag}_{20}$ and $\mathrm{Ag}_{21} \mathrm{NCs}$.

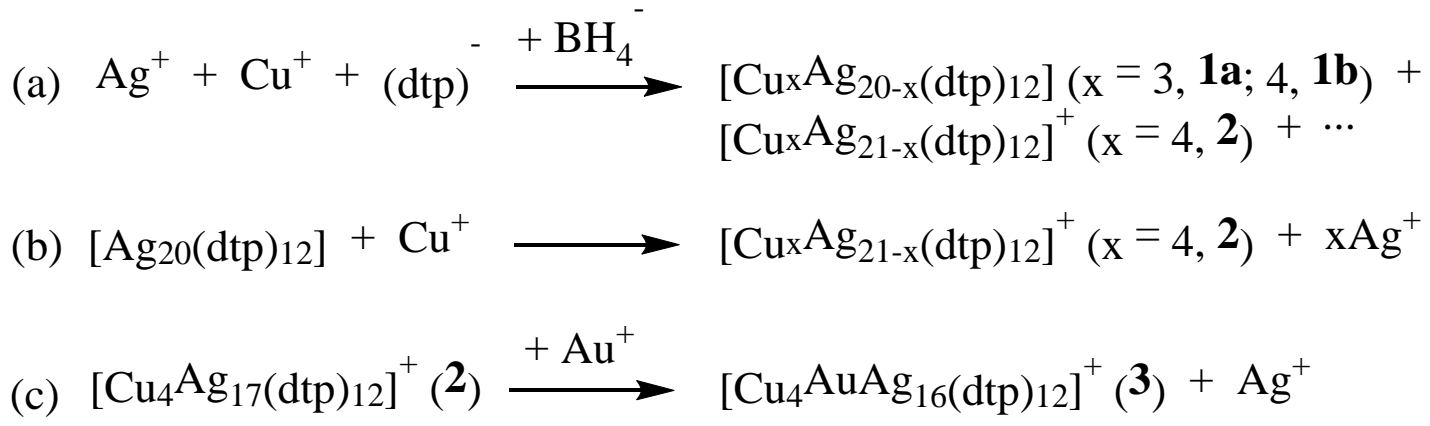

Scheme 1. (a) A one-pot synthesis of bimetallic NCs $\left(\mathrm{M}_{20}\right.$ and $\left.\mathrm{M}_{21}\right)$. The synthesis of (b) Cu-doped bimetallic NC $\left(\mathrm{M}_{21}\right)$, and (c) a trimetallic NC $\left(\mathrm{M}_{21}\right)$.

\section{B. NMR SPECTROSCOPY}

The ${ }^{31} \mathrm{P}\left\{{ }^{1} \mathrm{H}\right\}$ spectra (FIG. S1-S3) of $\mathbf{1 - 3}$ revealed single resonance, respectively, at 98.3, 93.5, and 93.6 ppm. Thus, the twelve di-isopropyl dithiophosphate (dtp) ligands are magnetically equivalent, indicating their rapid movement in solution by swapping onto the cluster surface. The broad resonance in the ${ }^{31} \mathrm{P}$ spectrum of $\mathbf{1}$ can be attributed to this movement being slower than in $\mathbf{2}$ and 3, because of the presence of an empty site on the surface of $\mathrm{M}_{20}$ cluster. The $\mathrm{PF}_{6}{ }^{-}$anion was found in the spectra of $\mathbf{2}$ and $\mathbf{3}$ with a septet resonance at $-143.0 \mathrm{ppm}\left({ }^{1} J_{\mathrm{PF}}=710 \mathrm{~Hz}\right)$. The ${ }^{1} \mathrm{H}$ spectra (FIG. S4-S6) of 1-3 showed resonances at around 1.4 and $4.9 \mathrm{ppm}$ with the integration ratio of $6: 1$, which match with the ratio of terminal and methine protons of the iso-propoxy groups.

\section{MASS SPECTROSCOPY}

ESI mass spectra of 1-3 display in a wide distribution. In the mass spectrum of $\mathbf{1}$ (FIG. 3), the molecular ion peaks displayed a distribution of $\left[\mathrm{Cu}_{\mathrm{x}} \mathrm{Ag}_{20-\mathrm{x}}\left\{\mathrm{S}_{2} \mathrm{P}\left(\mathrm{O}^{i} \mathrm{Pr}\right)_{2}\right\}_{12}\right.$ $\left.+\mathrm{Ag}^{+}\right]^{+}(\mathrm{x}=1-7)$ with the most intense peak corresponding to $\left[\mathrm{Cu}_{4} \mathrm{Ag}_{16}\left\{\mathrm{~S}_{2} \mathrm{P}\left(\mathrm{O}{ }^{i} \mathrm{Pr}\right)_{2}\right\}_{12}\right.$ $\left.+\mathrm{Ag}^{+}\right]^{+}$(exp. m/z: 4647.3758, calc. 4647.3053). Mass difference of $\mathrm{m} / \mathrm{z} \sim 44$ between adjacent peaks is attributed to the difference of atomic mass between $\mathrm{Cu}$ and $\mathrm{Ag}$. The number of $\mathrm{Cu}$ atoms ranging from 1 to 7 is clearly seen in the mass spectrum, which is different from the composition determined by $\mathrm{X}$-ray crystallography $(\mathrm{x}=3.5)$. It can 
be assumed that the ion peaks $(\mathrm{x}=1-7)$ are produced when the rearrangement process occurs in either the gas phase or the crystals dissolved in solution for sample preparation. Therefore, the molecular ion peaks show a range of distribution. On the other hand, we cannot separate the co-crystals of $\left[\mathrm{Cu}_{\mathrm{x}} \mathrm{Ag}_{20-\mathrm{x}}\left\{\mathrm{S}_{2} \mathrm{P}\left(\mathrm{O}^{i} \mathrm{Pr}\right)_{2}\right\}_{12}\right](\mathrm{x}=3,4)$ by column chromatography or TLC due to their very similar polarities. It is worthwhile to mention that Negishi's group developed a method to separate $\operatorname{Au}_{25-\mathrm{x}} \mathrm{Ag}_{\mathrm{x}}(\mathrm{SR})_{18}(\mathrm{x}=$ 0 -4) mixture, ${ }^{42}$ which unfortunately does not work in our case. Similarly, the mass spectrum of 2 displays a molecular ion peak distribution of $\left[\mathrm{Cu}_{\mathrm{x}} \mathrm{Ag}_{21-\mathrm{x}}\left\{\mathrm{S}_{2} \mathrm{P}\left(\mathrm{O}{ }^{i} \mathrm{Pr}\right)_{2}\right\}_{12}\right]^{+}$ $(\mathrm{x}=0-6)$ (FIG. S7). The most intense peak corresponds to the formula of $\left[\mathrm{Cu}_{3} \mathrm{Ag}_{18}\left\{\mathrm{~S}_{2} \mathrm{P}\left(\mathrm{O}^{i} \mathrm{Pr}\right)_{2}\right\}_{12}\right]^{+}$(exp. m/z: 4691.2714, calc. 4691.2788), which is close to the composition determined by X-ray diffraction $(x=4)$. In the case of 3 (FIG. S8), the molecular ion peaks also display a distribution of $\left[\mathrm{Cu}_{\mathrm{x}} \mathrm{AuAg} \mathrm{Ag}_{20-\mathrm{x}}\left\{\mathrm{S}_{2} \mathrm{P}\left(\mathrm{O}^{i} \mathrm{Pr}\right)_{2}\right\}_{12}\right]^{+}(\mathrm{x}$ $=0-7$ ) with the most intense peak corresponding to $\left[\mathrm{Cu}_{3} \mathrm{AuAg}_{17}\left\{\mathrm{~S}_{2} \mathrm{P}\left(\mathrm{O}^{i} \mathrm{Pr}\right)_{2}\right\}_{12}\right]^{+}$(exp. $\mathrm{m} / \mathrm{z}$ : 4779.5147, calc. 4779.3434). The proportion of $\mathrm{Au}$ in the latter distribution remains unchanged, suggesting a mono-substitution of Ag by Au in 3. It is worthwhile to mention that the ESI mass spectrum acquired from the single crystals of the mixed $\mathrm{Cu}(\mathrm{I}) / \mathrm{Ag}(\mathrm{I})$ hydride $\left[\mathrm{Cu}_{4} \mathrm{Ag}_{3}(\mathrm{H})\left\{\mathrm{E}_{2} \mathrm{P}\left(\mathrm{O}^{i} \mathrm{Pr}\right)_{2}\right\}_{6}\right](\mathrm{E}=\mathrm{S}$, Se) also shows a wide distribution of molecular ion peaks, corresponding to $\left[\mathrm{Cu}_{\mathrm{x}} \mathrm{Ag} \mathrm{g}_{7-\mathrm{x}}(\mathrm{H})\left\{\mathrm{E}_{2} \mathrm{P}\left(\mathrm{O}^{i} \mathrm{Pr}\right)_{2}\right\}_{6}+\right.$ $\left.\mathrm{Ag}^{+}\right]^{+}(\mathrm{x}=0-7) .{ }^{36,43}$ Presumably metal exchanges occur in the gas phase.

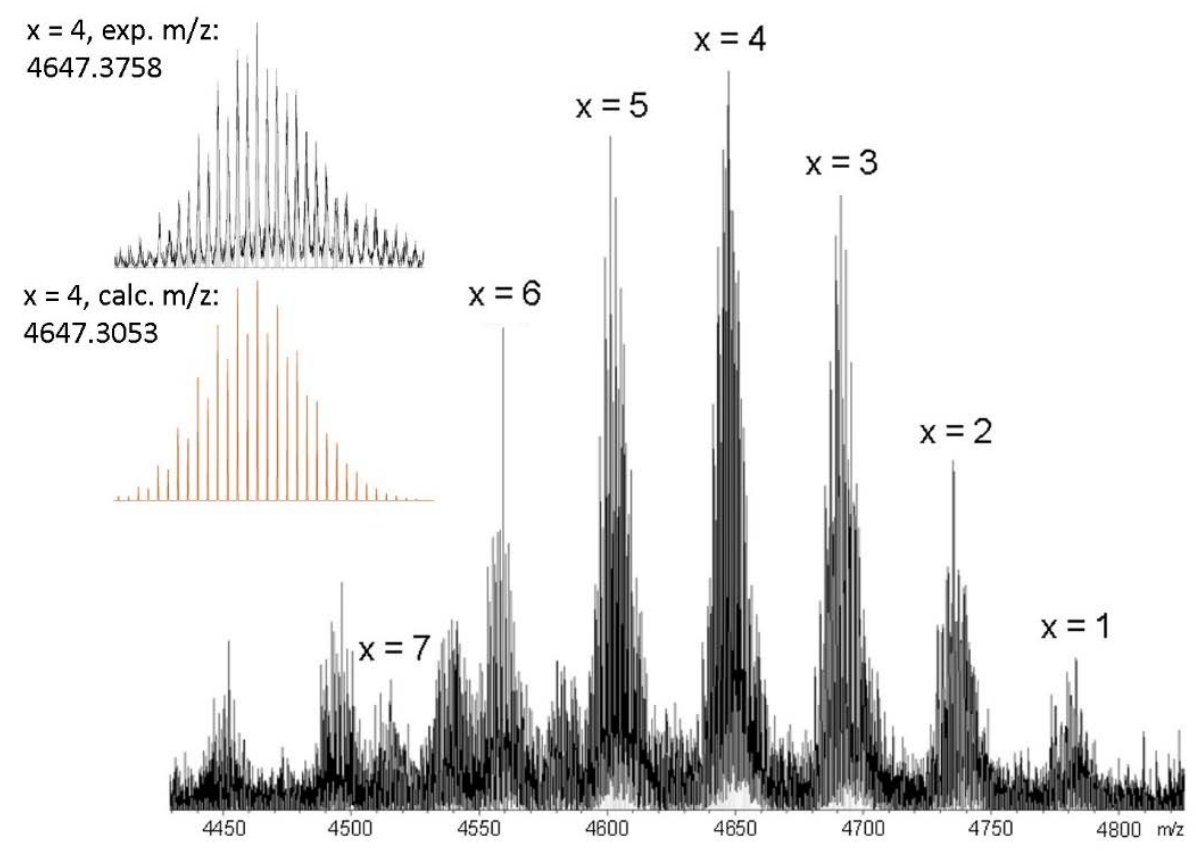

FIG. 3. Positive-mode ESI-MS spectrum of 1 . The distribution of molecular ion peaks corresponds to $\left[\mathrm{Cu}_{\mathrm{x}} \mathrm{Ag}_{20-\mathrm{x}}\left\{\mathrm{S}_{2} \mathrm{P}\left(\mathrm{O}^{i} \mathrm{Pr}\right)_{2}\right\}_{12}+\mathrm{Ag}^{+}\right]^{+}(\mathrm{x}=1-7)$.

\section{STRUCTURAL ANALYSIS}


Crystals of composition $\left\{[\mathbf{1} \mathbf{a}]_{0.5}[\mathbf{1 b}]_{0.5}\right\}$ were obtained from slow evaporation of an acetone solution containing compound $\mathbf{1}$. The $\mathbf{M}_{20}$ framework consists of a silvercentered icosahedral core $\left(\mathrm{Ag} @ \mathrm{Ag}_{12}\right)$ capped by seven outer metal $\left(\mathrm{Cu}_{\mathrm{x}} \mathrm{Ag}_{7-\mathrm{x}}\right)$ atoms (FIG. 4a), which is further stabilized by twelve dtp ligands (FIG. 4b). The whole cluster possesses an ideal $C_{3}$ symmetry with a 3-fold axis passing through the centers of two eclipsed triangular faces of the icosahedron. The only difference between 1a and $\left[\mathrm{Ag}_{20}\left\{\mathrm{~S}_{2} \mathrm{P}\left(\mathrm{O}^{i} \mathrm{Pr}\right)_{2}\right\}_{12}\right]^{23}$ is that four outer capping Ag atoms in the later are replaced by $\mathrm{Cu}$ atoms in the former. Indeed, compared with the homometallic $\left.\mathrm{Ag}_{20}\left\{\mathrm{~S}_{2} \mathrm{P}\left(\mathrm{O}^{i} \mathrm{Pr}\right)_{2}\right\}_{12}\right]$ relative, the electron densities on the seven capping positions are all significantly reduced, contrarily to that of the $\mathrm{M}_{13}$ centered icosahedral core that remain all the same and are consistent with full Ag occupation. This result indicates that the four $\mathrm{Cu}$ atoms are randomly disordered on the seven outer positions. A careful refinement led to a total occupancy of 3.5 for $\mathrm{Cu}$, corresponding to a co-crystallization of 50\% [Cu $\left.\mathrm{Cu}_{3} \mathrm{Ag}_{17}\left\{\mathrm{~S}_{2} \mathrm{P}\left(\mathrm{O}^{i} \mathrm{Pr}\right)_{2}\right\}_{12}\right](\mathbf{1 a})$ and $50 \%\left[\mathrm{Cu}_{4} \mathrm{Ag}_{16}\left\{\mathrm{~S}_{2} \mathrm{P}\left(\mathrm{O}^{i} \mathrm{Pr}\right)_{2}\right\}_{12}\right]$ (1) $)$. Hence, the molecular formula in $\mathbf{1}$ was determined as $\left\{[\mathbf{1 a}]_{0.5}[\mathbf{1 b}]_{0.5}\right\}$. The $\mathrm{Ag}_{\text {cent }}-\mathrm{Ag}_{\text {ico }}$ and $\mathrm{Ag}_{\text {ico }}-\mathrm{Ag}_{\text {ico }}$ distances in $\mathbf{1}$ are in the range of 2.7360(11) - 2.8197(11) $\AA$ (avg.

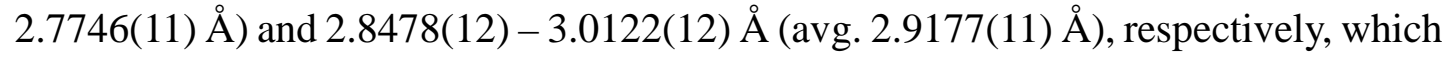
are similar to that in $\left[\mathrm{Ag}_{20}\left\{\mathrm{~S}_{2} \mathrm{P}\left(\mathrm{O}^{i} \mathrm{Pr}\right)_{2}\right\}_{12}\right](2.7299(5)-2.8244(5) \AA$, avg. 2.7785(5) $\AA$ and 2.8606(5) - 3.0179(5) $\AA$, avg. 2.9216(5) $\AA$ ). The average $\mathrm{M}_{\text {cap }}$-Agico distance in 1 (2.9542(13) $\AA$ ) is significantly shorter than in the $\mathrm{Ag}_{20}$ relative (2.9769(5) $\AA$ ) by $\sim 0.02$ $\AA$. It is attributed to the shorter atomic radii of $\mathrm{Cu}$ located on the $\mathrm{M}_{\text {cap }}$ position.

Crystals of $\mathbf{2}$ were grown from the slow evaporation of acetone solution. Comparing with the $\mathrm{M}_{20}$ core revealed in $\left\{[\mathbf{1} \mathbf{a}]_{0.5}[\mathbf{1 b}]_{0.5}\right\}$, the $\mathrm{M}_{21}$ framework is a simple addition of one metal atom (on the $C_{3}$ axis) to the capping position of 1a. With a total of eight outer metal atoms $\left(\mathrm{Cu}_{\mathrm{x}} \mathrm{Ag}_{8-\mathrm{x}}\right)$ capping the $\mathrm{Ag}_{13}$ centered icosahedron, the resulting $\mathrm{M}_{21}$ core has an ideal $D_{3}$ symmetry (FIG. 4c). It is further protected by twelve dtp ligands, which lower the symmetry to $C_{3}$ (FIG. $4 \mathrm{~d}$ ), leading to a structure similar to that of the homometallic $\left[\mathrm{Ag}_{21}\left\{\mathrm{~S}_{2} \mathrm{P}\left(\mathrm{O}^{i} \mathrm{Pr}\right)_{2}\right\}_{12}\right]^{+} .{ }^{24}$ Again, the $\mathrm{Cu}$ atoms only occupy the capping positions and are randomly disordered. The final refinement showed a total occupancy of 4 for the $\mathrm{Cu}$ atoms on the eight capping positions (FIG. 2). Therefore, the molecular formula is $\left[\mathrm{Cu}_{4} \mathrm{Ag}_{17}\left\{\mathrm{~S}_{2} \mathrm{P}\left(\mathrm{O}^{i} \mathrm{Pr}\right)_{2}\right\}_{12}\right] \mathrm{PF}_{6}$. The analysis of the metal distances in 2 shows similar trends as in $\left\{[\mathbf{1 a}]_{0.5}[\mathbf{1 b}]_{0.5}\right\}$. The $\mathrm{Ag}_{\text {cent }}-\mathrm{Ag}_{\text {ico }}$ and $\mathrm{Ag}_{\text {ico-}}-\mathrm{Ag}_{\text {ico }}$ distances in 2 are in the range of 2.7557(9) - 2.8020(8) $\AA$ (avg.

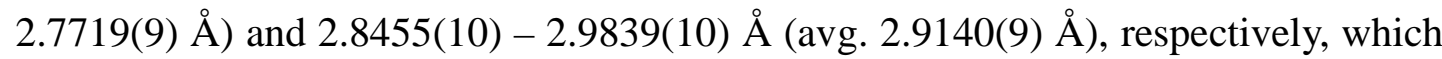
are similar to $\left[\mathrm{Ag}_{21}\left\{\mathrm{~S}_{2} \mathrm{P}\left(\mathrm{O}^{i} \mathrm{Pr}\right)_{2}\right\}_{12}\right] \mathrm{PF}_{6}$ (2.7542(8) - 2.8159(8) $\AA$, avg. 2.7801(8) $\AA$ and 2.8420(9) - 3.0255(9) $\AA$, avg. 2.9385(9) $\AA$ ). A significantly shorter average $\mathrm{M}_{\text {cap }}-\mathrm{Ag}_{\text {ico }}$ distance in 2 than in its Ag$_{21}$ relative (2.950(1) $\AA$ vs. 2.9811(10) $\AA$ ) was also observed. 
Unfortunately, good-quality single crystals of $\mathbf{3}$ suitable to collect decent X-ray diffraction data could not be obtained. A preliminary X-ray diffraction study showed that the highest electron density (higher than that for Ag) appeared on the central position ( $\mathrm{M}_{\mathrm{cent}}$ ), which can be reasonably assigned to Au. In our previous researches on isoelectronic $\mathrm{Au}_{\mathrm{x}} \mathrm{Ag}_{21-\mathrm{x}}$ alloy NCs, we have shown the neat preference for $\mathrm{Au}$ to occupy the central position. ${ }^{11-12,16}$ Accordingly, the $\mathrm{M}_{21}$ framework in $\mathbf{3}$ is likely to be an Au-centered $\mathrm{Ag}_{12}$ icosahedron capped by eight metal ( $\left.\mathrm{Cu}_{\mathrm{x}} \mathrm{Ag} \mathrm{g}_{8-\mathrm{x}}\right)$ atoms (FIG. 4e), the whole framework being further protected by twelve dtp ligands.

(a)

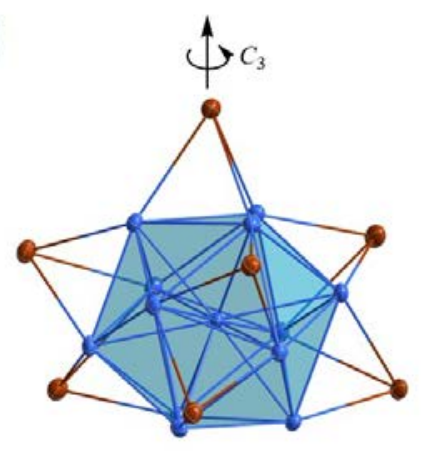

$C_{3}$ symmetry

(b)

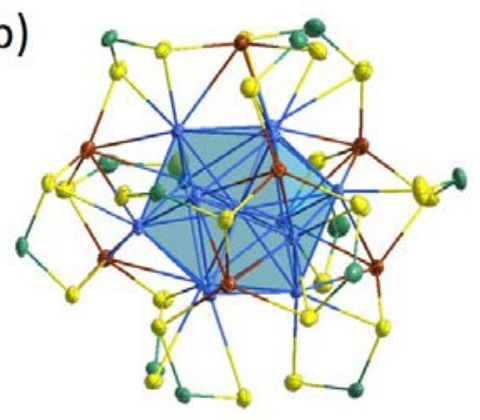

$C_{3}$ symmetry

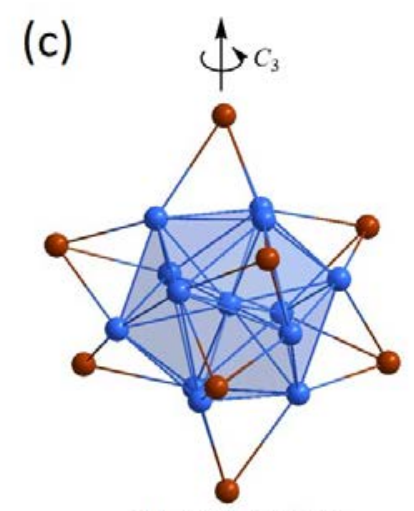

$D_{3}$ symmetry

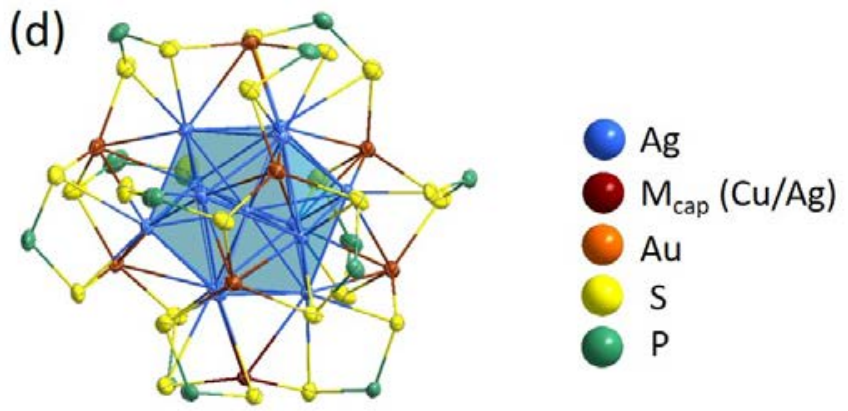

$C_{3}$ symmetry

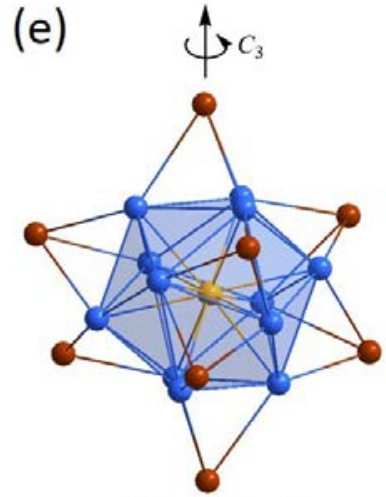

$D_{3}$ symmetry

Fig. 4. (a) The $\mathrm{M}_{20}$ framework of $\left\{[\mathbf{1} \mathbf{a}]_{0.5}[\mathbf{1 b}]_{0.5}\right\}$, and (b) full molecule of $\left\{[\mathbf{1 a}]_{0.5}[\mathbf{1 b}]_{0.5}\right\}$ with isopropoxy groups omitted. (c) The $\mathbf{M}_{21}$ framework of 2, and (d) full molecule of $\mathbf{2}$ with isopropoxy groups omitted. (e) The trimetallic $\mathbf{M}_{21}$ NC core, $\mathrm{Cu}_{\mathrm{x}} \mathrm{AuAg} 20-\mathrm{x}$.

\section{E. ELECTRONIC ABSORPTION SPECTROSCOPY}

The solution UV-Vis absorption spectra (FIG. 5a) of $\mathbf{1}$ in both powder and crystal forms and $\left[\mathrm{Ag}_{20}\left\{\mathrm{~S}_{2} \mathrm{P}\left(\mathrm{O}^{i} \mathrm{Pr}\right)_{2}\right\}_{12}\right]$ are nearly identical. They exhibit two major absorption bands around 355 and $422 \mathrm{~nm}$ (TABLE SI). With two major bands at 382 and $422 \mathrm{~nm}$, the absorption spectrum of 2 is also very similar to that of 
$\left[\mathrm{Ag}_{21}\left\{\mathrm{~S}_{2} \mathrm{P}\left(\mathrm{O}^{i} \mathrm{Pr}\right)_{2}\right\}_{12}\right]^{+}$(FIG. 5c and S9). The low-energy feature (a shoulder peak) at 473 and $480 \mathrm{~nm}$ in the $\mathrm{M}_{20}$ and $\mathrm{M}_{21}$ nanoclusters, respectively, is of large intraicosahedron MMCT nature due to the fact that the frontier orbitals of the 8-electron alloy are nearly independent from the capping metal ions (see below). ${ }^{12}$ Therefore, the substitution by $\mathrm{Cu}^{+}$atoms at $\mathrm{M}_{\text {cap }}$ positions does not perturb the characteristic absorption band of $480 \mathrm{~nm}$. Contrarily to that of $\mathbf{2}$, the absorption bands of $\mathbf{3}$ at 373, 413, and $464 \mathrm{~nm}$ are blue-shifted with respect to that of 2 and $\left[\mathrm{Ag}_{21}\left\{\mathrm{~S}_{2} \mathrm{P}\left(\mathrm{O}{ }^{i} \mathrm{Pr}\right)_{2}\right\}_{12}\right]^{+}$ (FIG. 5b). The larger HOMO-LUMO gap of 3, which arises from the central, more electronegative gold atom to induce larger center-to-surface charge transfer within the icosahedral core, results in the hypsochromic absorption band. ${ }^{11,12,16}$
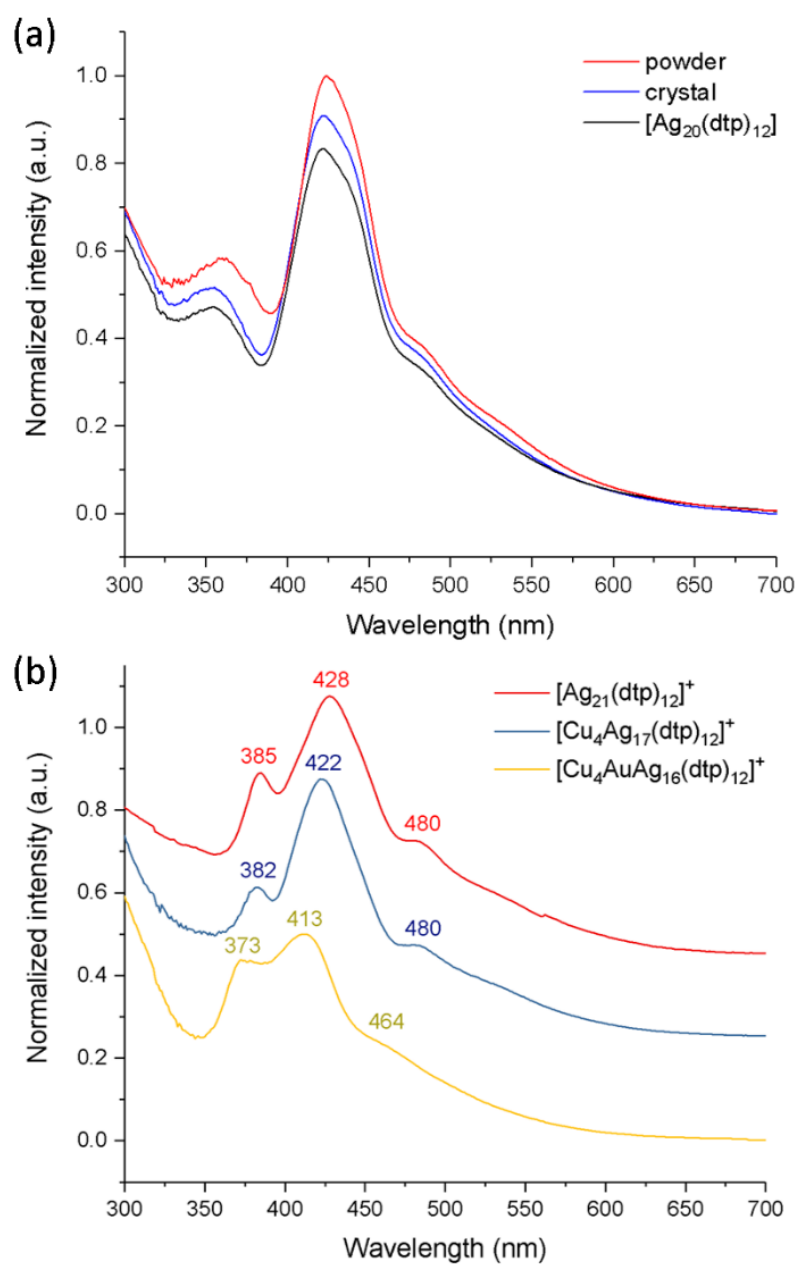

FIG. 5. (a) The absorption spectra of $\mathbf{1}$ in powder (red line), crystal (blue line), and $\left[\mathrm{Ag}_{20}\left\{\mathrm{~S}_{2} \mathrm{P}\left(\mathrm{O}^{i} \mathrm{Pr}\right)_{2}\right\}_{12}\right]$ (black line) in 2-MeTHF. (b) The stacked absorption spectra of $\left[\mathrm{Ag}_{21}\left\{\mathrm{~S}_{2} \mathrm{P}\left(\mathrm{O}^{i} \mathrm{Pr}\right)_{2}\right\}_{12}\right]^{+}$(red line), $\quad\left[\mathrm{Cu}_{4} \mathrm{Ag}_{17}\left\{\mathrm{~S}_{2} \mathrm{P}\left(\mathrm{O}^{i} \mathrm{Pr}\right)_{2}\right\}_{12}\right]^{+}$(green line), and $\left[\mathrm{Cu}_{4} \mathrm{AuAg}_{16}\left\{\mathrm{~S}_{2} \mathrm{P}\left(\mathrm{O}^{i} \mathrm{Pr}\right)_{2}\right\}_{12}\right]^{+}$(blue line) in 2-MeTHF.

\section{F. DFT COMPUTATIONAL ANALYSIS}


Compounds 1-3, as well as their homometallic $\mathrm{Ag}_{20}$ and $\mathrm{Ag}_{21}$ analogues were investigated by DFT calculations at the BP86/Def2-TZVP level of calculations. For the sake of computational limitations, the $\mathrm{S}_{2} \mathrm{P}\left(\mathrm{O}^{i} \mathrm{Pr}\right)_{2}$ ligands were replaced by $\mathrm{S}_{2} \mathrm{PH}_{2}$ models, a simplification which has been proved to be reasonable in many past investigations. ${ }^{10-14,23-24,36,41,43}$ The computed simplified models are labelled 1'-3' in the followings. In previous calculations ${ }^{10-12,41}$ and in a comprehensive investigation on site preference to be published, we showed that in this family of $\mathrm{M}_{20}$ and $\mathrm{M}_{21}$ Ag-rich compounds, copper always prefers occupying capping positions, whereas Au occupies preferentially the icosahedron center. Such site preferences are consistent with what was found for other systems. ${ }^{20-22,44}$ Then, in this work we assume the copper and gold atoms occupying capping and central positions, respectively, in full consistency with the X-ray structures of 1-3 (see above).

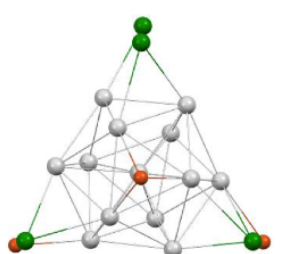

1

$\Delta \mathrm{E}=0.3 \mathrm{kcal} / \mathrm{mol}$ $\Delta \mathrm{G}=0.0 \mathrm{kcal} / \mathrm{mol}$ $\Delta \mathrm{E}_{\mathrm{H}-\mathrm{L}}=1.51 \mathrm{eV}$

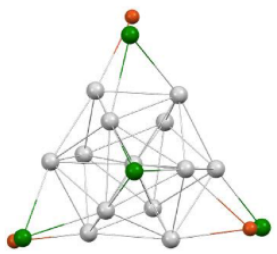

5

$\Delta \mathrm{E}=1.6 \mathrm{kcal} / \mathrm{mol}$

$\Delta \mathrm{G}=2.1 \mathrm{kcal} / \mathrm{mol}$ $\Delta \mathrm{E}_{\mathrm{H}-\mathrm{L}}=1.56 \mathrm{eV}$

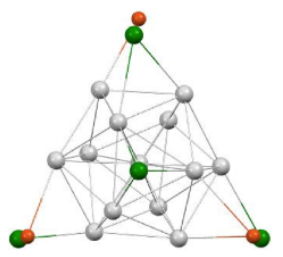

9

$\Delta \mathrm{E}=3.1 \mathrm{kcal} / \mathrm{mol}$

$\Delta \mathrm{G}=3.0 \mathrm{kcal} / \mathrm{mol}$ $\Delta \mathrm{E}_{\mathrm{H}-\mathrm{L}}=1.56 \mathrm{eV}$

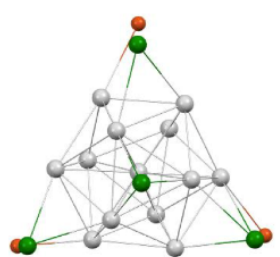

2

$\Delta \mathrm{E}=0.0 \mathrm{kcal} / \mathrm{mol}$ $\Delta \mathrm{G}=1.0 \mathrm{kcal} / \mathrm{mol}$ $\Delta \mathrm{E}_{\mathrm{H}-\mathrm{L}}=1.59 \mathrm{eV}$

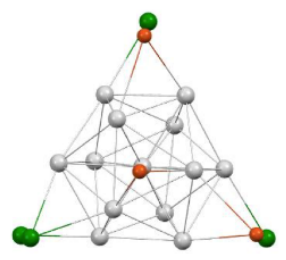

6

$\Delta \mathrm{E}=3.2 \mathrm{kcal} / \mathrm{mol}$ $\Delta \mathrm{G}=2.3 \mathrm{kcal} / \mathrm{mol}$ $\Delta \mathrm{E}_{\mathrm{H}-\mathrm{L}}=1.50 \mathrm{eV}$

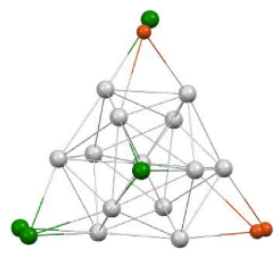

10

$\Delta \mathrm{E}=3.4 \mathrm{kcal} / \mathrm{mol}$

$\Delta \mathrm{G}=3.1 \mathrm{kcal} / \mathrm{mo}$ $\Delta \mathrm{E}_{\mathrm{H}-\mathrm{L}}=1.52 \mathrm{eV}$

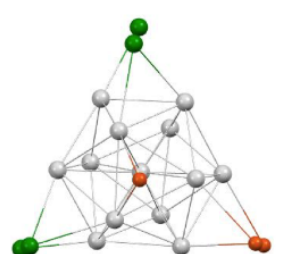

3

$\Delta \mathrm{E}=2.4 \mathrm{kcal} / \mathrm{mol}$ $\Delta \mathrm{G}=1.3 \mathrm{kcal} / \mathrm{mol}$ $\Delta \mathrm{E}_{\mathrm{H}-\mathrm{L}}=1.49 \mathrm{eV}$

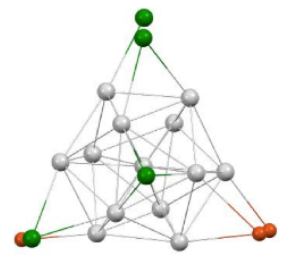

7

$\Delta \mathrm{E}=1.8 \mathrm{kcal} / \mathrm{mol}$ $\Delta G=2.5 \mathrm{kcal} / \mathrm{mol}$ $\Delta \mathrm{E}_{\mathrm{H}-\mathrm{L}}=1.54 \mathrm{eV}$

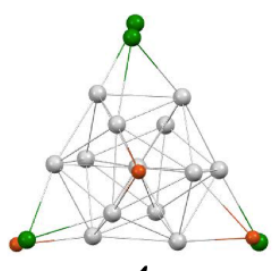

4

$\Delta \mathrm{E}=1.3 \mathrm{kcal} / \mathrm{mol}$

$\Delta \mathrm{G}=1.5 \mathrm{kcal} / \mathrm{mol}$

$\Delta \mathrm{E}_{\mathrm{H}-\mathrm{L}}=1.51 \mathrm{eV}$

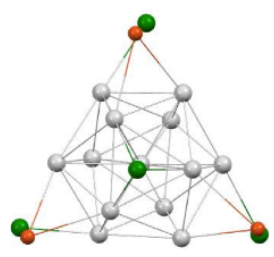

8

$\Delta \mathrm{E}=4.4 \mathrm{kcal} / \mathrm{mol}$

$\Delta \mathrm{G}=2.9 \mathrm{kcal} / \mathrm{mol}$ $\Delta \mathrm{E}_{\mathrm{H}-\mathrm{L}}=1.63 \mathrm{eV}$

FIG. 6. Metal cores of the 10 computed positional isomers of 1a' with their relative energies $(\Delta \mathrm{E})$, relative free energies $(\Delta \mathrm{G})$ and HOMO-LUMO gaps $\left(\Delta \mathrm{E}_{\mathrm{H}-\mathrm{L}}\right)$. Color code: grey $=$ Ag(icosahedral core), green $=\mathrm{Ag}$ (capping), red $=\mathrm{Cu}$. 
Considering first 1a', there are 10 ways of distributing the $3 \mathrm{Cu}$ atoms over the 7 capping positions, assuming $C_{3}$ symmetry for the unsubstituted metal framework. The metal cores of the corresponding positional isomers are given in FIG. 6, together with some relevant energetics. It makes quite clear that they all are close in energy, lying within a range of $\sim 4 \mathrm{kcal} / \mathrm{mol}$, both in relative energy $(\Delta \mathrm{E})$ or free energy $(\Delta G)$, and half of them lie in a $\sim 2 \mathrm{kcal} / \mathrm{mol}$ range. This result supports the fact that such nearly isoenergetic isomers are difficult to separate, leading to occupational statistical disorder on the capping positions in the X-ray structure. No structural tendency can be traced to explain these small energy differences, which are likely to result from a compromise between several weak factors. Very similar results are found for the 9 positional isomers of 1b' (FIG. 7), which all lie in a range of $\sim 3 \mathrm{kcal} / \mathrm{mol}$.

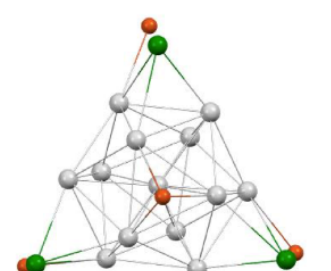

1

$\Delta \mathrm{E}=0.0 \mathrm{kcal} / \mathrm{mol}$ $\Delta \mathrm{G}=0.0 \mathrm{kcal} / \mathrm{mol}$ $\Delta \mathrm{E}_{\mathrm{H}-\mathrm{L}}=1.54 \mathrm{eV}$

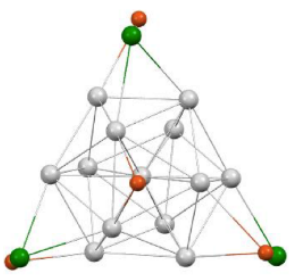

4

$\Delta \mathrm{E}=1.3 \mathrm{kcal} / \mathrm{mol}$ $\Delta \mathrm{G}=0.8 \mathrm{kcal} / \mathrm{mol}$ $\Delta \mathrm{E}_{\mathrm{H}-\mathrm{L}}=1.52 \mathrm{eV}$

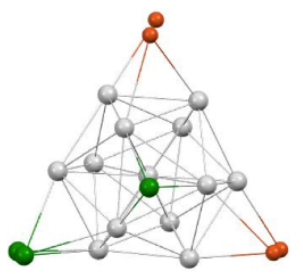

7

$\Delta \mathrm{E}=3.6 \mathrm{kcal} / \mathrm{mol}$

$\Delta \mathrm{G}=1.2 \mathrm{kcal} / \mathrm{mol}$

$\Delta \mathrm{E}_{\mathrm{H}-\mathrm{L}}=1.57 \mathrm{eV}$

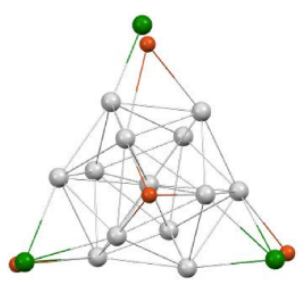

2
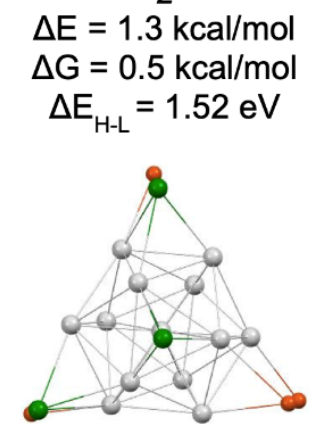

5

$\Delta \mathrm{E}=1.4 \mathrm{kcal} / \mathrm{mol}$

$\Delta G=1.1 \mathrm{kcal} / \mathrm{mol}$

$\Delta \mathrm{E}_{\mathrm{H}-\mathrm{L}}=1.59 \mathrm{eV}$

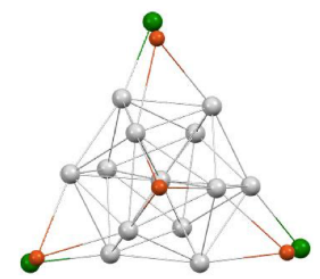

8

$\Delta \mathrm{E}=4.3 \mathrm{kcal} / \mathrm{mol}$

$\Delta \mathrm{G}=1.7 \mathrm{kcal} / \mathrm{mol}$

$\Delta \mathrm{E}_{\mathrm{H}-\mathrm{L}}=1.62 \mathrm{eV}$

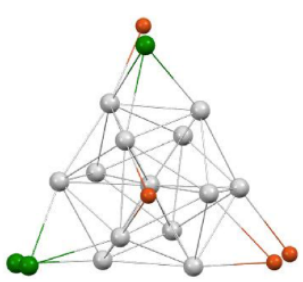

3

$\Delta \mathrm{E}=1.6 \mathrm{kcal} / \mathrm{mol}$ $\Delta \mathrm{G}=0.6 \mathrm{kcal} / \mathrm{mol}$ $\Delta \mathrm{E}_{\mathrm{H}-\mathrm{L}}=1.50 \mathrm{eV}$

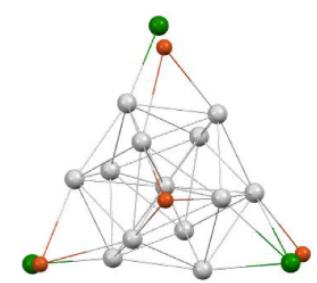

6

$\Delta \mathrm{E}=2.7 \mathrm{kcal} / \mathrm{mol}$

$\Delta \mathrm{G}=1.2 \mathrm{kcal} / \mathrm{mol}$

$\Delta \mathrm{E}_{\mathrm{H}-\mathrm{L}}=1.53 \mathrm{eV}$

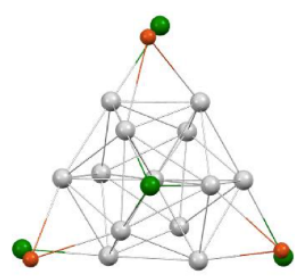

9

$\Delta \mathrm{E}=3.2 \mathrm{kcal} / \mathrm{mol}$

$\Delta G=1.9 \mathrm{kcal} / \mathrm{mol}$

$\Delta \mathrm{E}_{\mathrm{H}-\mathrm{L}}=1.57 \mathrm{eV}$ 
FIG. 7. Metal cores of the 9 computed positional isomers of 1b' with their relative energies $(\Delta \mathrm{E})$, relative free energies $(\Delta \mathrm{G})$ and HOMO-LUMO gaps $\left(\Delta \mathrm{E}_{\mathrm{H}-\mathrm{L}}\right)$. Color code: grey $=$ Ag(icosahedral core), green $=\mathrm{Ag}($ capping $)$, red $=\mathrm{Cu}$.

The energetics of the 12 positional isomers of the $\mathrm{M}_{21}$ species 2' (FIG. 8) and 3' (FIG. 9) is also similar to that of their $\mathbf{M}_{20}$ relatives 1a' and $\mathbf{1 b}$ '. The gold-centered species 3' is the most noteworthy in the fact all the structures lie in a range of less than $1.5 \mathrm{kcal} / \mathrm{mol}$, both in $\Delta \mathrm{E}$ and $\Delta \mathrm{G}$, a value not significantly different from 0 at our level of calculations.

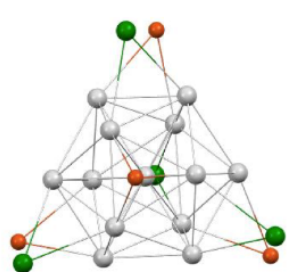

1

$\Delta \mathrm{E}=1.7 \mathrm{kcal} / \mathrm{mol}$

$\Delta \mathrm{G}=0.0 \mathrm{kcal} / \mathrm{mol}$

$\Delta \mathrm{E}_{\mathrm{H}-\mathrm{L}}=1.68 \mathrm{eV}$

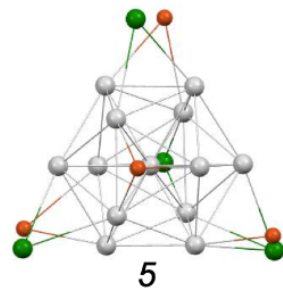

$\Delta \mathrm{E}=1.4 \mathrm{kcal} / \mathrm{mol}$ $\Delta \mathrm{G}=0.7 \mathrm{kcal} / \mathrm{mol}$ $\Delta \mathrm{E}_{\mathrm{H}-\mathrm{L}}=1.62 \mathrm{eV}$

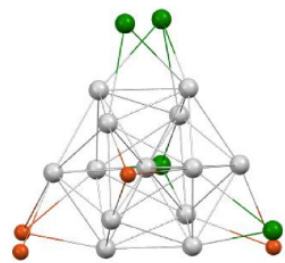

9

$\Delta \mathrm{E}=2.5 \mathrm{kcal} / \mathrm{mol}$

$\Delta \mathrm{G}=1.3 \mathrm{kcal} / \mathrm{mol}$ $\Delta \mathrm{E}_{\mathrm{H}-\mathrm{L}}=1.66 \mathrm{eV}$

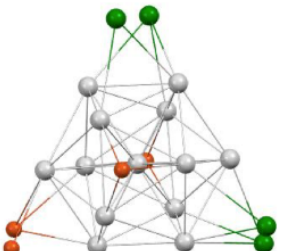

2

$\Delta \mathrm{E}=0.7 \mathrm{kcal} / \mathrm{mol}$

$\Delta \mathrm{G}=0.1 \mathrm{kcal} / \mathrm{mol}$

$\Delta \mathrm{E}_{\mathrm{H}-\mathrm{L}}=1.56 \mathrm{eV}$

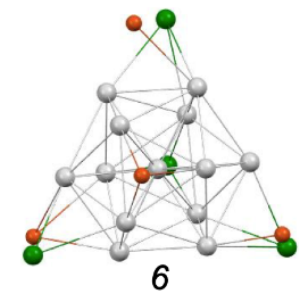

$\Delta \mathrm{E}=2.0 \mathrm{kcal} / \mathrm{mol}$

$\Delta \mathrm{G}=0.8 \mathrm{kcal} / \mathrm{mol}$

$\Delta \mathrm{E}_{\mathrm{H}-\mathrm{L}}=1.66 \mathrm{eV}$

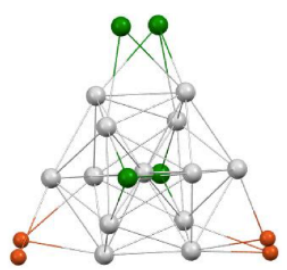

10

$\Delta \mathrm{E}=2.5 \mathrm{kcal} / \mathrm{mol}$

$\Delta G=1.4 \mathrm{kcal} / \mathrm{mol}$

$\Delta \mathrm{E}_{\mathrm{H}-\mathrm{L}}=1.66 \mathrm{eV}$

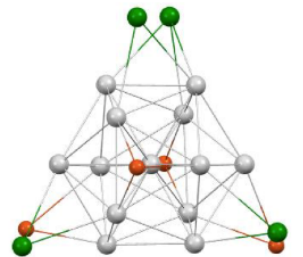

3

$\Delta \mathrm{E}=1.5 \mathrm{kcal} / \mathrm{mol}$

$\Delta G=0.4 \mathrm{kcal} / \mathrm{mol}$

$\Delta \mathrm{E}_{\mathrm{H}-\mathrm{L}}=1.59 \mathrm{eV}$

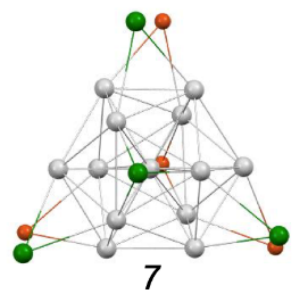

$\Delta \mathrm{E}=2.6 \mathrm{kcal} / \mathrm{mol}$

$\Delta G=0.8 \mathrm{kcal} / \mathrm{mol}$

$\Delta \mathrm{E}_{\mathrm{H}-\mathrm{L}}=1.75 \mathrm{eV}$

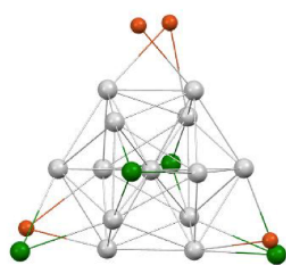

11

$\Delta \mathrm{E}=3.5 \mathrm{kcal} / \mathrm{mol}$

$\Delta \mathrm{G}=1.5 \mathrm{kcal} / \mathrm{mol}$

$\Delta \mathrm{E}_{\mathrm{H}-\mathrm{L}}=1.67 \mathrm{eV}$

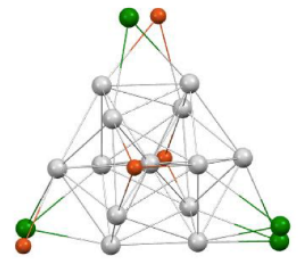

4

$\Delta \mathrm{E}=0.0 \mathrm{kcal} / \mathrm{mol}$

$\Delta \mathrm{G}=0.7 \mathrm{kcal} / \mathrm{mol}$

$\Delta \mathrm{E}_{\mathrm{H}-\mathrm{L}}=1.58 \mathrm{eV}$

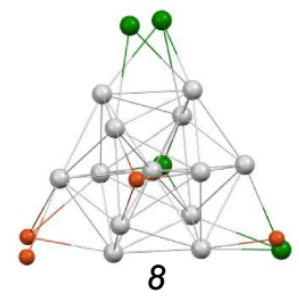

$\Delta \mathrm{E}=2.2 \mathrm{kcal} / \mathrm{mol}$

$\Delta \mathrm{G}=1.2 \mathrm{kcal} / \mathrm{mol}$

$\Delta \mathrm{E}_{\mathrm{H}-\mathrm{L}}=1.61 \mathrm{eV}$

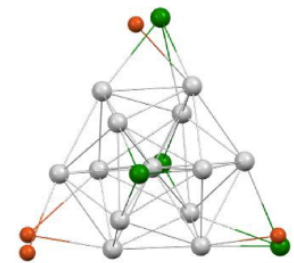

12

$\Delta \mathrm{E}=3.0 \mathrm{kcal} / \mathrm{mol}$

$\Delta \mathrm{G}=2.0 \mathrm{kcal} / \mathrm{mol}$

$\Delta \mathrm{E}_{\mathrm{H}-\mathrm{L}}=1.68 \mathrm{eV}$

FIG. 8. Metal cores of the 12 computed positional isomers of 2' with their relative energies $(\Delta \mathrm{E})$, relative free energies $(\Delta \mathrm{G})$ and HOMO-LUMO gaps $\left(\Delta \mathrm{E}_{\mathrm{H}-\mathrm{L}}\right)$. Color code: grey $=$ Ag(icosahedral core), green $=\mathrm{Ag}$ (capping), red $=\mathrm{Cu}$. 


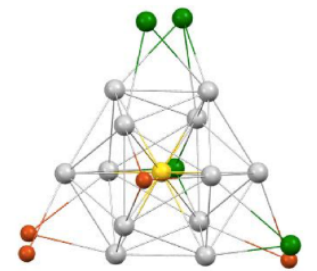

1

$\Delta \mathrm{E}=0.0 \mathrm{kcal} / \mathrm{mol}$ $\Delta \mathrm{G}=0.0 \mathrm{kcal} / \mathrm{mol}$ $\Delta \mathrm{E}_{\mathrm{H}-\mathrm{L}}=1.73 \mathrm{eV}$

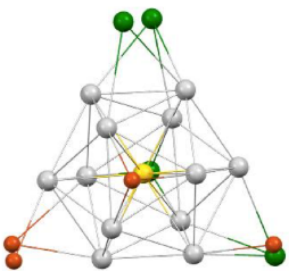

5

$\Delta \mathrm{E}=0.2 \mathrm{kcal} / \mathrm{mol}$ $\Delta \mathrm{G}=0.2 \mathrm{kcal} / \mathrm{mol}$ $\Delta \mathrm{E}_{\mathrm{H}-\mathrm{L}}=1.73 \mathrm{eV}$

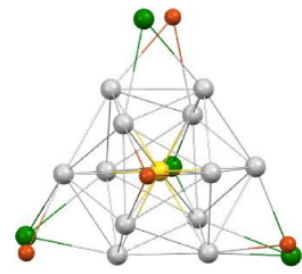

9

$\Delta \mathrm{E}=0.4 \mathrm{kcal} / \mathrm{mol}$

$\Delta \mathrm{G}=0.7 \mathrm{kcal} / \mathrm{mol}$

$\Delta \mathrm{E}_{\mathrm{H}-\mathrm{L}}=1.78 \mathrm{eV}$

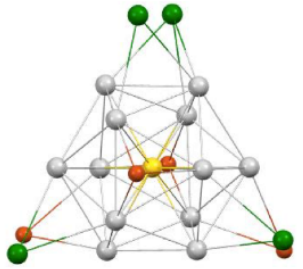

2

$\Delta \mathrm{E}=0.1 \mathrm{kcal} / \mathrm{mol}$ $\Delta \mathrm{G}=0.0 \mathrm{kcal} / \mathrm{mol}$

$\Delta \mathrm{E}_{\mathrm{H}-\mathrm{L}}=1.71 \mathrm{eV}$

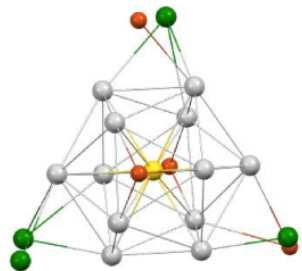

6

$\Delta \mathrm{E}=0.2 \mathrm{kcal} / \mathrm{mol}$

$\Delta G=0.4 \mathrm{kcal} / \mathrm{mol}$

$\Delta \mathrm{E}_{\mathrm{H}-\mathrm{L}}=1.70 \mathrm{eV}$

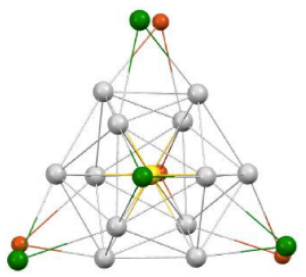

10

$\Delta \mathrm{E}=1.0 \mathrm{kcal} / \mathrm{mol}$

$\Delta G=0.8 \mathrm{kcal} / \mathrm{mol}$

$\Delta \mathrm{E}_{\mathrm{H}-\mathrm{L}}=1.89 \mathrm{eV}$

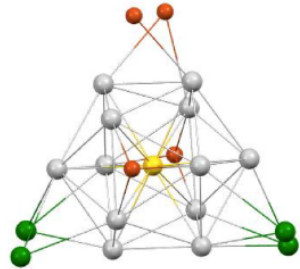

3

$\Delta \mathrm{E}=0.2 \mathrm{kcal} / \mathrm{mol}$ $\Delta G=0.1 \mathrm{kcal} / \mathrm{mol}$ $\Delta \mathrm{E}_{\mathrm{H}-\mathrm{L}}=1.69 \mathrm{eV}$

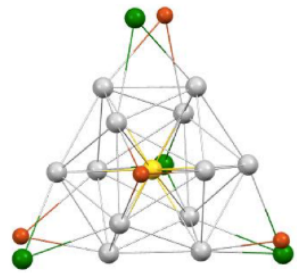

7

$\Delta \mathrm{E}=0.2 \mathrm{kcal} / \mathrm{mol}$ $\Delta \mathrm{G}=0.5 \mathrm{kcal} / \mathrm{mol}$ $\Delta \mathrm{E}_{\mathrm{H}-\mathrm{L}}=1.78 \mathrm{eV}$

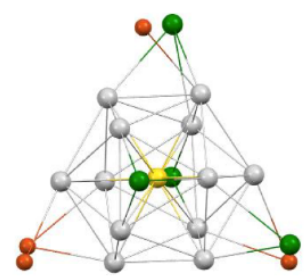

11

$\Delta \mathrm{E}=1.1 \mathrm{kcal} / \mathrm{mol}$

$\Delta G=1.2 \mathrm{kcal} / \mathrm{mol}$

$\Delta \mathrm{E}_{\mathrm{H}-\mathrm{L}}=1.79 \mathrm{eV}$

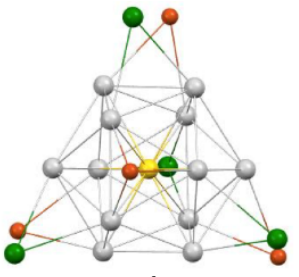

4

$\Delta \mathrm{E}=0.0 \mathrm{kcal} / \mathrm{mol}$ $\Delta \mathrm{G}=0.2 \mathrm{kcal} / \mathrm{mol}$ $\Delta \mathrm{E}_{\mathrm{H}-\mathrm{L}}=1.79 \mathrm{eV}$

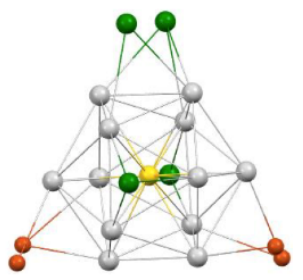

8

$\Delta \mathrm{E}=1.0 \mathrm{kcal} / \mathrm{mol}$ $\Delta \mathrm{G}=0.6 \mathrm{kcal} / \mathrm{mol}$ $\Delta \mathrm{E}_{\mathrm{H}-\mathrm{L}}=1.78 \mathrm{eV}$

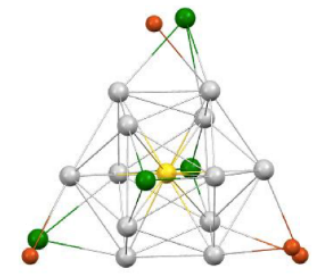

12

$\Delta \mathrm{E}=1.3 \mathrm{kcal} / \mathrm{mol}$

$\Delta \mathrm{G}=1.4 \mathrm{kcal} / \mathrm{mol}$

$\Delta \mathrm{E}_{\mathrm{H}-\mathrm{L}}=1.80 \mathrm{eV}$

FIG. 9. Metal cores of the 12 computed positional isomers of 3' with their relative energies $(\Delta \mathrm{E})$, relative free energies $(\Delta \mathrm{G})$ and HOMO-LUMO gaps $\left(\Delta \mathrm{E}_{\mathrm{H}-\mathrm{L}}\right)$. Color code: yellow $=$ gold, grey $=\mathrm{Ag}($ icosahedron $)$, green $=\mathrm{Ag}($ capping $)$, red $=\mathrm{Cu}$.

Although they have quite similar electronic structures, the positional isomers of a given composition differ a bit in their HOMO-LUMO gaps, suggesting slightly different electronic absorption spectra. This is confirmed by TD-DFT calculations performed at the CAM-B3LYP/Def2-TZVP level on the various optimized structure. The major computed electronic UV-vis transitions vary by less than 30 $\mathrm{nm}$ (15 nm in average) within a series of isomers. This is illustrated in FIG. S1114, which show the TD-DFT-simulated spectra of the isomers with the largest and lowest HOMO-LUMO gaps, together with that of the most stable one in free energy. The reason for this weak optical sensitivity to the number and positions of $\mathrm{Cu}$ atoms in the clusters lies in the fact that their frontier orbitals are of superatomic nature, i.e. mainly localized on the icosahedral $\left[\mathrm{Ag}_{13}\right]^{5+}$ core, the 
configuration of which being $1 \mathrm{~S}^{2} 1 \mathrm{P}^{6} 1 \mathrm{D}^{0} 2 \mathrm{~S}^{0}$. Thus the superatomic $1 \mathrm{P}$ orbitals constitute the highest occupied levels (split in $a+e$ in ideal $C_{3}$ symmetry) and the $1 \mathrm{D}$ orbitals constitute the lowest vacant levels (split in $a+e+e$ ). This is illustrated in FIG. S15, which shows the Kohn-Sham MO diagram of the $C_{3}\left[\mathrm{Ag}_{21}\left(\mathrm{~S}_{2} \mathrm{PH}_{2}\right)_{12}\right]^{+}$ model, with their \% spatial localizations. One can see that the contribution from the 8 capping Ag atoms to the 1P levels is negligible and small (10-21\%) to the $1 \mathrm{D}$ levels. The $\left[\mathrm{Ag}_{21}\left(\mathrm{~S}_{2} \mathrm{PH}_{2}\right)_{12}\right]^{+}$band of lowest energy is of large $1 \mathrm{P}(1 e) \rightarrow 1 \mathrm{D}(2 e)$ nature. The intense intermediate band at $394 \mathrm{~nm}$ is mainly associated with the $1 \mathrm{P}(1 a) \rightarrow 1 \mathrm{D}(2 e)$ transition. The band at higher energy has a large $1 \mathrm{P}(1 a) \rightarrow 2 \mathrm{~S}(3 a)$ contribution. Thus, not only $\left[\mathrm{Ag}_{21}\left(\mathrm{~S}_{2} \mathrm{PH}_{2}\right)_{12}\right]^{+}$, but also all its less symmetrical copper alloys, these three absorption bands (and especially that of lowest energy) are mainly of intra-icosahedron nature, with small participation from the outer capping metals. The situation in the structurally-related $C_{3}\left[\mathrm{Ag}_{20}\left(\mathrm{~S}_{2} \mathrm{PH}_{2}\right)_{12}\right]$ model , as well as that in its copper alloys, is very similar. This is why the UV-vis behavior of the doped species do not differ importantly from that of their homometallic relatives. On the other hand, replacing by $\mathrm{Au}$ the central $\mathrm{Ag}$ atom in the superatomic $\left[\mathrm{Ag}_{13}\right]^{5+}$ core, tends to stabilize the occupied $1 \mathrm{~S}$ and $1 \mathrm{P}$ orbitals, resulting in a HOMO-LUMO gap increase upon doping and thus a blue-shifted UV-vis spectrum. The TD-DFT-simulated spectra of $\left[\mathrm{Ag}_{20}\left(\mathrm{~S}_{2} \mathrm{PH}_{2}\right)_{12}\right], \mathbf{1 a}$ ' and $\mathbf{1 b}$ ' (FIG. 10a) and $\left[\mathrm{Ag}_{21}\left(\mathrm{~S}_{2} \mathrm{PH}_{2}\right)_{12}\right]^{+}, 2^{\prime}$ and 3' (FIG. 10b) are in a quite good agreement with their experimental counterparts of FIG. 5. 
(a)

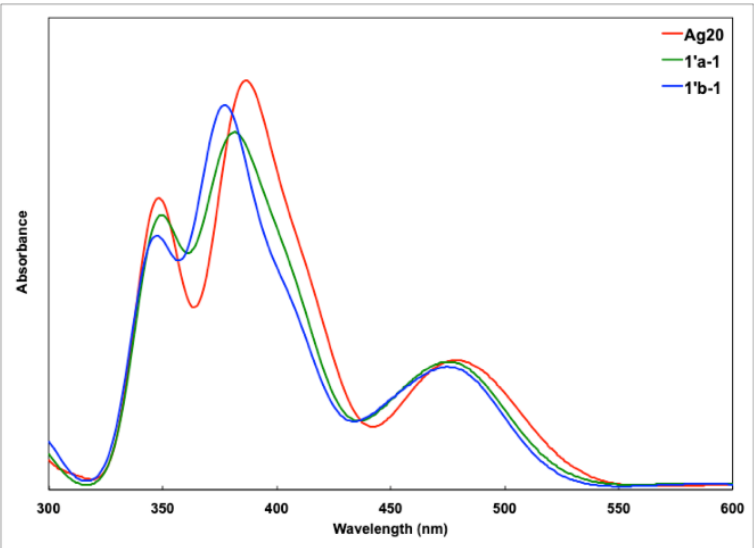

(b)

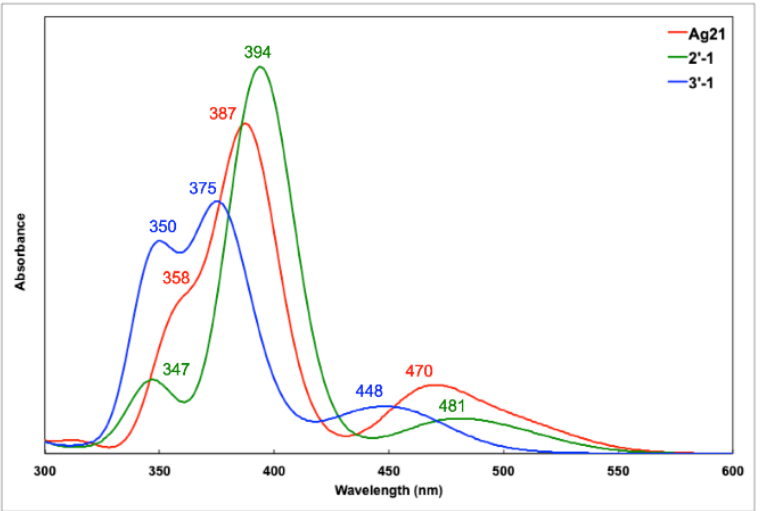

FIG. 10. The TD-DFT-simulated absorption spectra of: (a) $\left[\mathrm{Ag}_{20}\left(\mathrm{~S}_{2} \mathrm{PH}_{2}\right)_{12}\right]$, 1a' and 1b'; (b) $\left[\mathrm{Ag}_{21}\left(\mathrm{~S}_{2} \mathrm{PH}_{2}\right)_{12}\right]^{+}, \mathbf{2}^{\prime}$ and 3'.

\section{CONCLUSION}

In conclusion, two bimetallic NCs, $\left[\mathrm{Cu}_{\mathrm{x}} \mathrm{Ag}_{20-\mathrm{x}}\left\{\mathrm{S}_{2} \mathrm{P}\left(\mathrm{O}^{i} \mathrm{Pr}\right)_{2}\right\}_{12}\right](\mathrm{x}=3-4)$ and $\left[\mathrm{Cu}_{4} \mathrm{Ag}_{17}\left\{\mathrm{~S}_{2} \mathrm{P}\left(\mathrm{O}^{i} \mathrm{Pr}\right)_{2}\right\}_{12}\right]^{+}$, were successfully synthesized from a one-pot reaction. The bimetallic $\mathrm{M}_{21} \mathrm{NC}$ can also be produced by $\mathrm{Cu}$-doping of $\left[\mathrm{Ag}_{20}\left\{\mathrm{~S}_{2} \mathrm{P}\left(\mathrm{O}{ }^{i} \mathrm{Pr}\right)_{2}\right\}_{12}\right]$ via metal exchange followed by addition reactions. The X-ray crystal structures show that $\mathrm{Cu}$ tends to replace $\mathrm{Ag}$ on the outer capping positions instead of the inner $\mathrm{Ag}_{13}$ centered icosahedron. DFT calculations indicate little difference between the preferences of $\mathrm{Cu}$ for the various outer capping positions. The nearly equivalency of the 8 outer positions for $\mathrm{Cu}$ locations results in a mixture of nearly degenerate positional isomers, in full agreement with the random distribution in the crystal of the $\mathrm{Cu}$ atoms over the eight NC outer positions. The characteristic low-energy absorption band centered at $480 \mathrm{~nm}$ has little influence against $\mathrm{Cu}$ replacement in both $\mathrm{M}_{20}$ and $\mathrm{M}_{21} \mathrm{NCs}$, indicating that the electronic transition is largely independent from the nature of the capping metal ions. A further doping reaction of Au atom into $\left[\mathrm{Cu}_{x} \mathrm{Ag}_{21-\mathrm{x}}\left\{\mathrm{S}_{2} \mathrm{P}\left(\mathrm{O}^{i} \mathrm{Pr}\right)_{2}\right\}_{12}\right]^{+}$formed a trimetallic nanocluster $\left[\mathrm{Cu}_{\mathrm{x}} \mathrm{AuAg} \mathrm{Ag}_{20 \mathrm{x}}\left\{\mathrm{S}_{2} \mathrm{P}\left(\mathrm{O}^{i} \mathrm{Pr}\right)_{2}\right\}_{12}\right]^{+}$, resulting a significant blue-shift 
in the absorption spectrum. These results present a nice addition to rare structurally characterized, copper-doped silver superatomic alloys.

\section{SUPPLEMENTARY MATERIAL}

See supplementary material for crystallographic data, ESI mass spectra, absorption, and NMR spectra.

\section{ACKNOWLEDGEMENTS}

This work was supported by the Ministry of Science and Technology of Taiwan (MOST 109-2113-M-259-008, 108-2923-M-259-001), the France-Taiwan ANRMOST program (project Nanoalloys) and the GENCI French national computer resource center (grant A0030807367).

\section{DATA AVAILABILITY}

The data that support the findings of this study are available within the article (and its supplementary material).

\section{REFERENCES}

${ }^{1}$ X. Song, W. Zhu, X. Ge, R. Li, S. Li, X. Chen, J. Song, J. Xie, X. Chen, H. Yang, "A New Class of NIR-II Gold Nanocluster-Based Protein Biolabels for In Vivo Tumor-Targeted Imaging,” Angew. Chem. Int. Ed. 60, 1306-1312 (2021).

${ }^{2}$ Y. Tao, M. Li, J. Ren, X. Qu, "Metal nanoclusters: novel probes for diagnostic and therapeutic applications,” Chem. Soc. Rev. 44, 8636-8663 (2015).

${ }^{3}$ C. M. Aikens, "Electronic and Geometric Structure, Optical Properties, and Excited State Behavior in Atomically Precise Thiolate-Stabilized Noble Metal Nanoclusters,” Acc. Chem. Res. 51, 3065-3073 (2018).

4 R. Jin, "Atomically precise metal nanoclusters: stable sizes and optical properties,” Nanoscale 7, 1549-1565 (2015).

${ }^{5}$ R. Jin, G. Li, S. Sharma, Y. Li, X. Du, "Toward Active-Site Tailoring in Heterogeneous Catalysis by Atomically Precise Metal Nanoclusters with Crystallographic Structures,” Chem. Rev. 121, 567-648 (2021).

${ }^{6}$ X. Kang, Y. Li, M. Zhu, R. Jin, “Atomically precise alloy nanoclusters: syntheses, structures, and properties,” Chem. Soc. Rev. 49, 6443-6514 (2020).

7 X. Kang, M. Zhu, "Tailoring the photoluminescence of atomically precise nanoclusters,” Chem. Soc. Rev. 48, 2422-2457 (2019).

${ }^{8}$ G. Soldan, M. A. Aljuhani, M. S. Bootharaju, L. G. AbdulHalim, M. R. Parida, A.-H. Emwas, O. F. Mohammed, O. M. Bakr, "Gold Doping of Silver 
Nanoclusters: A 26-Fold Enhancement in the Luminescence Quantum Yield,” Angew. Chem. Int. Ed. 55, 5749-5753 (2016).

${ }^{9}$ M. van der Linden, A. J. van Bunningen, L. Amidani, M. Bransen, H. Elnaggar, P. Glatzel, A. Meijerink, F. M. F. de Groot, "Single Au Atom Doping of Silver Nanoclusters,” ACS Nano 12, 12751-12760 (2018).

${ }^{10}$ R. P. B. Silalahi, K. K. Chakrahari, J.-H. Liao, S. Kahlal, Y.-C. Liu, M,-H. Chiang, J.-Y. Saillard, C. W. Liu, "Synthesis of Two-Electron Bimetallic Cu-Ag and $\mathrm{Cu}-\mathrm{Au}$ Clusters by using $\left[\mathrm{Cu}_{13}\left(\mathrm{~S}_{2} \mathrm{CN}^{n} \mathrm{Bu}_{2}\right)_{6}(\mathrm{C} \equiv \mathrm{CPh})_{4}\right]^{+}$as a Template,”

Chem. Asian J. 13, 500-504 (2018).

${ }^{11}$ Y.-R. Lin, P. V. V. N. Kishore, J.-H. Liao, S. Kahlal, Y.-C. Liu, M.-H. Chiang, J.-Y. Saillard, C. W. Liu, "Synthesis, structural characterization and transformation of an eight-electron superatomic alloy, [Au@Ag $\left.{ }_{19}\left\{\mathrm{~S}_{2} \mathrm{P}(\mathrm{OPr})_{2}\right\}_{12}\right]$,” Nanoscale 10, 6855-6860 (2018). 12 W.-T. Chang, P.-Y. Lee, J.-H. Liao, K. K. Chakrahari, S. Kahlal, Y.-C. Liu, M,H. Chiang, J.-Y. Saillard, C. W. Liu, “Eight-Electron Silver and Mixed Gold/Silver Nanoclusters Stabilized by Selenium Donor Ligands,” Angew. Chem. Int. Ed. 56, 10178-10182 (2017).

13 T.-H. Chiu, J.-H. Liao, F. Gam, I. Chantrenne, S. Kahlal, J.-Y. Saillard, C. W. Liu, Homoleptic Platinum/Silver Superatoms Protected by Dithiolates: Linear Assemblies of Two and Three Centered Icosahedra Isolobal to $\mathrm{Ne}_{2}$ and $\mathrm{I}_{3}{ }^{-}$,” J. Am. Chem. Soc. 141, 12957-12961 (2019).

${ }^{14}$ S. K. Barik, T.-H. Chiu, Y.-C. Liu, M.-H. Chiang, F. Gam, I. Chantrenne, S. Kahlal, J.-Y. Saillard, C. W. Liu, "Mono- and hexa-palladium doped silver nanoclusters stabilized by dithiolates,” Nanoscale 11, 14581-14586 (2019).

15 J. Yan, H. Su, H. Yang, S. Malola, S. Lin, H. Häkkinen, N. Zheng, “Total Structure and Electronic Structure Analysis of Doped Thiolated Silver [MAg $\left._{24}(\mathrm{SR})_{18}\right]^{2-}(\mathrm{M}=\mathrm{Pd}, \mathrm{Pt})$ Clusters,” J. Am. Chem. Soc. 137, 11880-11883 (2015).

${ }^{16}$ M. S. Bootharaju, C. P. Joshi, M. R. Parida, O. F. Mohammed, O. M. Bakr, "Templated Atom-Precise Galvanic Synthesis and Structure Elucidation of a [Ag$\left.{ }_{24} \mathrm{Au}(\mathrm{SR})_{18}\right]^{-}$Nanocluster,” Angew. Chem. Int. Ed. 55, 922-926 (2016).

${ }^{17}$ X. Liu, J. Yuan, C. Yao, J. Chen, L. Li, X. Bao, J. Yang, Z. Wu, “Crystal and Solution Photoluminescence of $\mathrm{MAg}_{24}(\mathrm{SR})_{18}(\mathrm{M}=\mathrm{Ag} / \mathrm{Pd} / \mathrm{Pt} / \mathrm{Au})$ Nanoclusters and Some Implications for the Photoluminescence Mechanisms,” J. Phys. Chem. C 121, 13848-13853 (2017).

${ }^{18}$ Z.-J. Guan, F. Hu, S.-F. Yuan, Z.-A. Nan, Y.-M. Lin, Q.-M. Wang, “The stability enhancement factor beyond eight-electron shell closure in thiacalix[4]areneprotected silver clusters,” Chem. Sci. 10, 3360-3365 (2019). 
${ }^{19}$ W. Du, X. Kang, S. Jin, D. Liu, S. Wang, M. Zhu, "Different Types of Ligand Exchange Induced by Au Substitution in a Maintained Nanocluster Template,” Inorg. Chem. 59, 1675-1681 (2020).

${ }^{20}$ X. Kang, X. Wei, S. Jin, Q. Yuan, X. Luan, Y. Pei, S. Wang, M. Zhu, R. Jin, "Rational construction of a library of $\mathrm{M}_{29}$ nanoclusters from monometallic to tetrametallic,” Proc. Natl. Acad. Sci. U. S. A. 116, 18834-18840 (2019).

${ }^{21}$ J. Yan, H. Yang, C. Hu, S. Malola, S. Lin, B. K. Teo, H. Häkkinen, N. Zheng, "Asymmetric Synthesis of Chiral Bimetallic $\left[\mathrm{Ag}_{28} \mathrm{Cu}_{12}(\mathrm{SR})_{24}\right]^{4-}$ Nanoclusters via Ion Pairing,” J. Am. Chem. Soc. 138, 12751-12754 (2016).

${ }^{22}$ X. Kang, H. Abroshan, S. Wang, M. Zhu, “Free Valence Electron Centralization Strategy for Preparing Ultrastable Nanoclusters and Their Catalytic Application,” Inorg. Chem. 58, 11000-11009 (2019).

${ }^{23}$ R. S. Dhayal, Y.-R. Lin, J.-H. Liao, Y.-J. Chen, Y.-C. Liu, M.-H. Chiang, S. Kahlal, J.-Y. Saillard, C. W. Liu, " $\left[\mathrm{Ag}_{20}\left\{\mathrm{~S}_{2} \mathrm{P}(\mathrm{OR})_{2}\right\}_{12}\right]$ : A Superatom Complex with a Chiral Metallic Core and High Potential for Isomerism,” Chem. Eur. J. 22, 9943-9947 (2016).

${ }^{24}$ R. S. Dhayal, J.-H. Liao, Y.-C. Liu, M.-H. Chiang, S. Kahlal, J.-Y. Saillard, C. W. Liu, " $\left[\mathrm{Ag}_{21}\left\{\mathrm{~S}_{2} \mathrm{P}\left(\mathrm{O}^{i} \mathrm{Pr}\right)_{2}\right\}_{12}\right]^{+}$: An Eight-Electron Superatom,” Angew. Chem. Int. Ed. 54, 3702-3706 (2015).

${ }^{25}$ D. D. Perrin, W. L. F. Armarego, "Purification of laboratory chemicals. $4^{\text {th }}$ Edition,” (Butterworth Heinemann Press, Oxford, 1996).

${ }^{26}$ G. J. Kubas, B. Monzyk, A. L. Crumbliss, “Tetrakis(Acetonitrile)Copper(I) Hexafluorophosphate,” Inorg. Synth. 19, 90-92 (1979).

${ }^{27}$ V. P. Wystrach, E. O. Hook, G. L. M. Christopher, “Notes - Basic Zinc Double Salts of O,O-Diakyl Phosphorodithioic Acids,” J. Org. Chem. 21, $705-707$ (1956).

${ }^{28}$ Gaussian 16, Revision A.03, M. J. Frisch, G. W. Trucks, H. B. Schlegel, G. E. Scuseria, M. A. Robb, J. R. Cheeseman, G. Scalmani, V. Barone, G. A. Petersson, H. Nakatsuji, X. Li, M. Caricato, A. V. Marenich, J. Bloino, B. G. Janesko, R. Gomperts, B. Mennucci, H. P. Hratchian, J. V. Ortiz, A. F. Izmaylov, J. L. Sonnenberg, D. Williams-Young, F. Ding, F. Lipparini, F. Egidi, J. Goings, B. Peng, A. Petrone, T. Henderson, D. Ranasinghe, V. G. Zakrzewski, J. Gao, N. Rega, G. Zheng, W. Liang, M. Hada, M. Ehara, K. Toyota, R. Fukuda, J. Hasegawa, M. Ishida, T. Nakajima, Y. Honda, O. Kitao, H. Nakai, T. Vreven, K. Throssell, J. A. Montgomery, Jr., J. E. Peralta, F. Ogliaro, M. J. Bearpark, J. J. Heyd, E. N. Brothers, K. N. Kudin, V. N. Staroverov, T. A. Keith, R. Kobayashi, J. Normand, K. Raghavachari, A. P. Rendell, J. C. Burant, S. S. Iyengar, J. Tomasi, M. Cossi, J. M. Millam, M. Klene, C. Adamo, R. Cammi, J. W. Ochterski, R. L. Martin, K. 
Morokuma, O. Farkas, J. B. Foresman, D. J. Fox, Gaussian, Inc., Wallingford CT, 2016.

${ }^{29}$ A. D. Becke, "Density-functional exchange-energy approximation with correct asymptotic behavior,” Phys. Rev. A, 38, 3098-3100 (1988).

30 J. P. Perdew, "Density-functional approximation for the correlation energy of the inhomogeneous electron gas,” Phys. Rev. B, 33, 8822-8824 (1986).

${ }^{31}$ A. Schaefer, H. Horn, R. J. Ahlrichs, "Fully optimized contracted Gaussian basis sets for atoms Li to Kr,” Chem. Phys. 97, 2571-2577 (1992).

32 A. Schaefer, C. Huber, R. J. Ahlrichs, "Fully optimized contracted Gaussian basis sets of triple zeta valence quality for atoms Li to Kr,” Chem. Phys. 100, 58295835 (1994).

${ }^{33}$ S. I. Gorelsky, AOMix program,http://www.sg-chem.net.

34 T. Yanai, D. Tew, N. Handy, “A new hybrid exchange-correlation functional using the Coulomb-attenuationg method (CAM-B3LYP),” Chem. Phys. Lett. 393, 51-57 (2004).

${ }^{35}$ Gauss View, Version 6.1, R. Dennington, T. A. Keith, M. Millam, Semichem Inc., Shawnee Mission, KS, 2016.

${ }^{36}$ Y.-J. Zhong, J.-H. Liao, T.-H. Chiu, Y.-Y. Wu, S. Kahlal, J.-Y. Saillard, C. W. Liu, "Hydride-encapsulated bimetallic clusters supported by 1,1-dithiolates," Chem. Commun. 56, 9300-9303 (2020).

${ }^{37}$ SADABS, “version 2014-11.0,” (Bruker Area Detector Absorption Corrextions, Bruker AXS Inc., Madison, WI, 2014).

38 SAINT, "V8.30A,” (Software for the CCD detector system, Bruker Analytical: Madison, WI, 2012).

${ }^{39}$ G. M. Sheldrick, “A short history of SHELX,” Acta Cryst. A 64, 112-122 (2008).

40 SHELXTL, “version 6.14,” (Bruker AXS Inc., Madison, Wisconsin, USA, 2003).

${ }^{41}$ S. Sharma, K. K. Chakrahari, J.-Y. Saillard, C. W. Liu, "Structurally Precise Dichalcogenolate-Protected Copper and Silver Superatomic Nanoclusters and Their Alloys,” Acc. Chem. Res. 51, 2475-2483 (2018).

${ }^{42}$ Y. Niihori, Y. Koyama, S. Watanabe, S. Hashimoto, S. Hossain, L, V. Nair, B. Kumar, W. Kurashige, Y. Negishi, “Atomic and Isomeric Separation of ThiolateProtected Alloy Clusters,” J. Phys. Chem. Lett. 9, 4930-4934 (2018).

${ }^{43}$ Y.-J. Zhong, J.-H. Liao, T.-H. Chiu, Y.-Y. Wu, S. Kahlal, M. J. McGlinchey, J.Y. Saillard, C. W. Liu, "Intercluster exchanges leading to hydride-centered bimetallic clusters: a multi-NMR, X-ray crystallographic, and DFT study,” Dalton Trans. 50, 4727-4734 (2021). 
${ }^{44}$ F. Alkan, P. Pandeya, C. M. Aikens, "Understanding the effect of doping on energetics and electronic structure for $\mathrm{Au}_{25}, \mathrm{Ag}_{25}$ and $\mathrm{Au}_{38}$ clusters,” J. Phys. Chem. C, 123, 9516-9527 (2019). 